\title{
Optimization of PhysicoChemical
} Parameters for Production of Cytotoxic Secondary Metabolites and Apoptosis Induction Activities in the Culture Extract of a Marine Algal-Derived Endophytic Fungus Aspergillus sp.

\author{
Sidhartha Taritla ${ }^{1}$, Madhuree Kumari ${ }^{1}$, Siya Kamat ${ }^{1}$, Sarita G. Bhat ${ }^{2}$ and C. Jayabaskaran ${ }^{1 *}$ \\ ${ }^{1}$ Department of Biochemistry, Indian Institute of Science, Bangalore, India, ${ }^{2}$ Department of Biotechnology, Cochin University of \\ Science and Technology, Kochi, India
}

OPEN ACCESS

Edited by:

Farhat Afrin,

Independent researcher, India

Reviewed by: Ahm Khurshid Alam,

University of Rajshahi, Bangladesh Sreenivasulu Kilari,

Mayo Clinic, United States

*Correspondence:

C. Jayabaskaran cjb@iisc.ac.in

Specialty section:

This article was submitted to Pharmacology of Anti-Cancer Drugs, a section of the journal

Frontiers in Pharmacology

Received: 21 April 2020 Accepted: 17 February 2021

Published: 26 April 2021

Citation:

Taritla S, Kumari M, Kamat S, Bhat SG and Jayabaskaran C (2021)

Optimization of PhysicoChemical Parameters for Production of Cytotoxic

Secondary Metabolites and Apoptosis Induction Activities in the Culture Extract of a Marine Algal-Derived Endophytic Fungus Aspergillus sp..

Front. Pharmacol. 12:542891. doi: 10.3389/fphar.2021.542891
The endophytic fungal community in the marine ecosystem has been demonstrated to be relevant source of novel and pharmacologically active secondary metabolites. The current study focused on the evaluation of cytotoxic and apoptosis induction potential in the culture extracts of endophytic fungi associated with Sargassum muticum, a marine brown alga. The cytotoxicity of the four marine endophytes, Aspergillus sp., Nigrospora sphaerica, Talaromyces purpureogenus, and Talaromyces stipitatus, was evaluated by the MTT assay on HeLa cells. Further, several physicochemical parameters, including growth curve, culture media, and organic solvents, were optimized for enhanced cytotoxic activity of the selected extract. The Aspergillus sp. ethyl acetate extract (ASE) showed maximum cytotoxicity on multiple cancer cell lines. Chemical investigation of the metabolites by gas chromatography-mass spectroscopy (GC-MS) showed the presence of several compounds, including quinoline, indole, 2,4-bis(1,1dimethylethyl) phenol, and hexadecenoic acid, known to be cytotoxic in ASE. The ASE was then tested for cytotoxicity in vitro on a panel of six human cancer cell lines, namely, HeLa (cervical adenocarcinoma), MCF-7 (breast adenocarcinoma), Hep G2 (hepatocellular carcinoma), A-549 (lung carcinoma), A-431 (skin/epidermis carcinoma), and LN-229 (glioblastoma). HeLa cells were most vulnerable to ASE treatment with an $I_{50}$ value of $24 \pm 2 \mu \mathrm{g} / \mathrm{ml}$. The mechanism of cytotoxicity exhibited by the ASE was further investigated on Hela cells. The results showed that the ASE was capable of inducing apoptosis in HeLa cells through production of reactive oxygen species, depolarization of mitochondrial membrane, and activation of the caspase-3 pathway, which shows a possible activation of the intrinsic apoptosis pathway. It also arrested the HeLa cells at the G2/M phase of the cell cycle, eventually leading to apoptosis. Through this study, we add to the knowledge about the marine algae associated with fungal endophytes and report its potential for purifying specific compounds responsible for cytotoxicity.

Keywords: marine macroalga, Sargassum muticum, endophytic fungi, Aspergillus sp., cytotoxic compounds, apoptosis 3 


\section{INTRODUCTION}

Cancer is an immense burden of disease on developing and developed nations, with enormous social and economic impacts. Even in the 21st century, more people die of cancer than a combination of several diseases. The complexity of this disease and overlapping signaling pathways pose a challenge for therapeutic approaches (Alves et al,, 2018). More than half of the anticancer drugs commercially available are either direct natural products or their derivatives (Veeresham, 2012). The Indian medicine system continues to prevail on natural sources. In the past, drugs derived from natural sources like medicinal plants have laid an invaluable foundation for the modern day discovery and developments of new drugs (Balunas and Kinghorn, 2005). However, the hurdle lies in evidence-based determination of the pharmacological properties of these drugs and extracts. Hence, scientific validation of these drugs and extracts is a vital part of pharmacology (Choudhury et al., 2016). Till date, the major treatment for cancer has been chemotherapy. There is an urgent need for the development of new anticancer drugs because of increasing resistance of cancer cells to the currently used anticancer drugs, rendering them ineffective. The inevitable side effects of this therapy pose a major hurdle in its application and therapeutic success. Moreover, cancer manifests itself in various forms, making its treatment even more challenging. This clearly unveils an intricate field of research that can give myriads of treatment modalities for the disease (Nurgali et al., 2018). Natural products have therefore been recognized as a promising alternative source in the search for new potent and pharmaceutically effective anticancer compounds.

Recently, the interest in marine microorganisms has grown due to the prospect of getting profuse biomass (Deshmukh et al., 2018; Kamat et al., 2020a) by in vitro culturing and subsequently appreciable amounts of secondary metabolites. It has been seen that among marine microorganisms, endophytic fungi of macroalgae show boundless potential to produce structurally diverse novel bioactive natural products (Zhang et al., 2016; Baracaldo et al., 2019; Kaddes et al., 2019). Most of these marine algal-derived fungi grow in an exceptionally extreme and inimitable habitat, which makes them capable to produce unusual secondary metabolites. This is simply because of their existence and adaptation to a distinct ecosystem (Flewelling et al., 2015; Wahaibi et al., 2019). Several studies have previously demonstrated the cytotoxic activities of marine endophytic extracts in cancer cells (Kamat et al., 2020a; Kamat et al., 2020b; Sajna et al., 2020). It has been observed that natural products provide apoptosis-modulating templates which can be extremely beneficial in management and therapy of cancer. Hence, it is imperative that apoptotic inducers, either in the form of crude extracts or as isolated compounds, be screened thoroughly (Motadi et al., 2020). In this study, we intended to evaluate the anticancer natural product potential of marine algae-associated endophytes. This could further help in developing novel lead molecules for developing drugs against cancer. To achieve this aim, four fungal strains associated with a marine alga Sargassum muticum were cultivated in vitro and tested for cytotoxic and induction of apoptosis by the fungal extracts.

Sargassum muticum is one of the common marine algae used in food and medicine in tropical and subtropical countries, including India. In traditional medicines, they are used as anticancer, antiviral, antidiabetic, anti-allergic, and antithrombotic agents (Zhu et al., 2006; Liu et al., 2012; Namvar et al., 2013).

Endophytic fungi residing inside S. muticum may also possess the bioactive potential as a result of genetic exchange and long-term symbiotic evolution with their host. Earlier, endophytic fungi and bacteria of plants used in traditional Chinese medicine have shown bioactive potential, very similar to their host plants (Miller et al., 2012).

Singh et al., 2016 have also studied the antioxidative activity of endophytic Cladosporium velox, and established its relationship with host plant Tinospora cordifolia.

Further, we report the cytotoxic activity and apoptosis induction by Aspergillus sp. ethyl acetate extract in HeLa cells. We support this observation by further investigating the molecular mechanisms triggering the event of apoptosis in HeLa cells (Scheme 1).

\section{MATERIALS AND METHODS}

\section{Materials}

Fungal growth media, potato dextrose agar (PDA) and potato dextrose broth (PDB) were procured from Himedia, India. 3-(4, 5-dimethylthiazole-2yl)-2 and 5-diphenyl tetrazolium bromide (MTT) reagents were bought from SRL-Ranbaxy. Ethyl acetate, hexane, chloroform, and dichloromethane were procured from Merck, India. Dulbecco's Modified Eagle's Medium (DMEM), dimethyl sulfoxide (DMSO), 5,5',6,6'-tetrachloro-1,1',3,3' tetraethylbenzimi-dazolylcarbocyanine iodide (JC-1), $2^{\prime}, 7^{\prime}$ dichlorodihydrofluorescein diacetate (DCFHDA), N-acetyl-Lcysteine (NAC), and Annexin-FITC/Propidium Iodide (PI) Staining Kit were procured from Sigma Aldrich, United States. Penicillin/streptomycin solution, GlutaMAX solution, TrypsinEDTA, and fetal bovine serum (FBS) were bought from GIBCOBRL. Doxorubicin was purchased from Calbiochem, India. Caspase 3, 7, and 10 Apoptosis Fluorometric Assay Kit was procured from G-Biosciences, United States. Apoptosis inhibitor "Z-VAD-FMK" was procured from Santa Cruz Biotechnology, United States. All chemicals and reagents used were of analytical grade.

\section{Human Cancer Cell Lines and Their Maintenance}

HeLa (cervical adenocarcinoma), MCF-7 (breast adenocarcinoma), Hep G2 (hepatocellular carcinoma), A549 (lung carcinoma), A-431 (epidermoid carcinoma), and LN-229 (glioblastoma) and HEK 293T (human embryonic kidney cell line) were procured from National Center for Cell Sciences (NCCS) Pune, India. Dulbecco's Modified Eagle's medium (DMEM) supplemented with 10\% FBS, 1\% (v/v) penicillin/ streptomycin solution, $1 \%(\mathrm{v} / \mathrm{v})$ GlutaMAX solution was used to grow and maintain cell lines (HeLa, A-431, A549, LN-229, and HEK 293T) at $37^{\circ} \mathrm{C}$ in a humidified $5 \% \mathrm{CO}_{2}$ atmosphere. Chinese Hamster Ovary (CHO), a non-cancer cell line was a kind gift from Prof. P. N. Rangarajan, Department of Biochemistry IISc Bangalore, India. Minimum Essential Medium Eagle (MEM) supplemented with 10\% FBS, 1\% (v/v) penicillin/ 


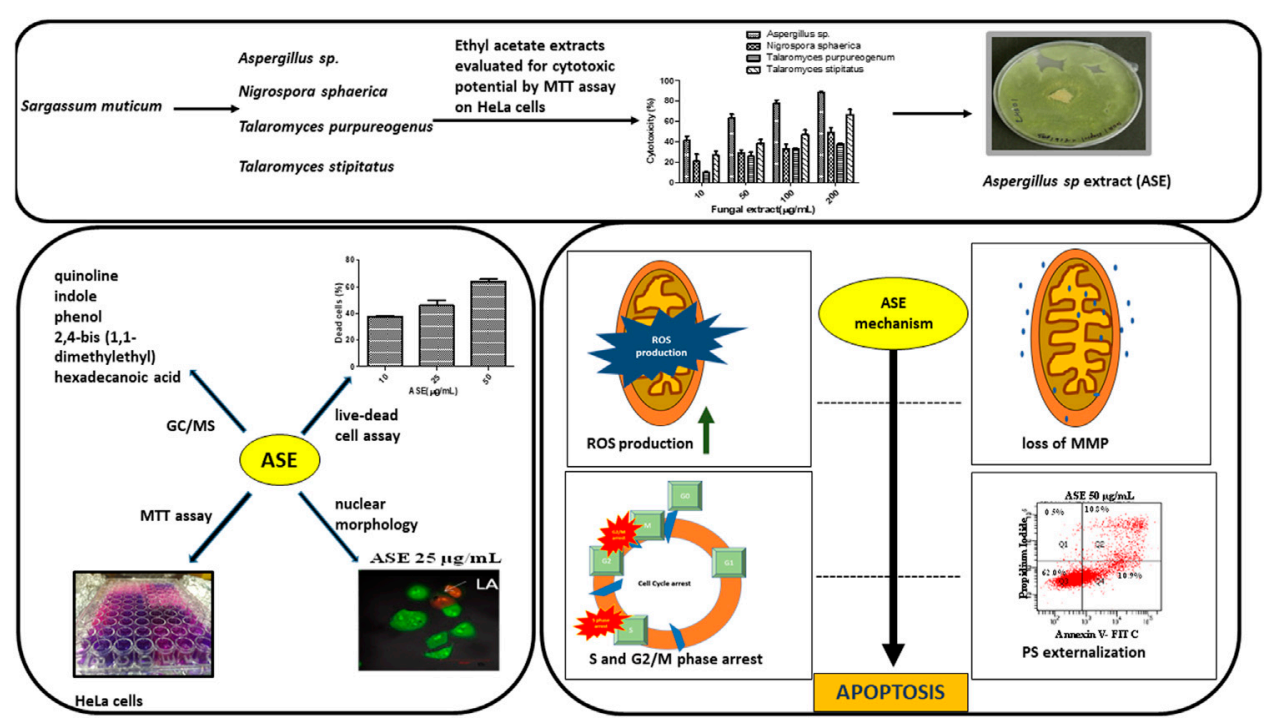

SCHEME 1 | Schematic diagram representing the screening of isolated fungi, optimization of physicochemical parameters, their cytotoxic potential, and mechanism of cell death induced by ASE in HeLa cells.

streptomycin solution, 1\% (v/v) MEM nonessential amino acid solution, and $1 \%(\mathrm{v} / \mathrm{v})$ GlutaMAX solution was used to grow and maintain $\mathrm{CHO}$ cell line at $37^{\circ} \mathrm{C}$ in a humidified $5 \%$ $\mathrm{CO}_{2}$ atmosphere

\section{Isolation and Identification of Endophytic Fungi From a Seaweed}

The seaweed S. muticum was collected from the Kovalam Coast, Thiruvananthapuram, Kerala, India, and brought to the laboratory along with sea water in a sterile polythene bag. Endophytic fungi were isolated adapting the protocol from Kjer et al., 2011. Further, the endophytic fungi were grown in PDB for 7 days at $28 \pm 2^{\circ} \mathrm{C}$, after which, genomic DNA was extracted. The internal transcribed spacer (ITS) region of rDNA was amplified and sequenced using primers ITS1 and ITS4. The sequences were compared with those available in GenBank using BLASTN. The isolated endophytic fungi were identified as Aspergillus sp., Talaromyces purpureogenus, Nigrospora sphaerica, and Talaromyces stipitatus. The ITS DNA sequences, thus obtained and downloaded sequences of their nearest neighbours were used to construct a phylogenetic tree using MEGA X (Minarni Artika et al., 2017; Kumar et al., 2018).

\section{Preparation of Endophytic Fungal Extracts}

The four isolated endophytic fungi were pregrown on PDA for 10 days at $28 \pm 2^{\circ} \mathrm{C}$. Thereafter, two $5 \mathrm{~mm}$ diameter agar discs of each endophyte were used to inoculate $300 \mathrm{ml}$ of PDB medium in a $1 \mathrm{~L}$ Erlenmeyer flask. These cultures were grown for 28 days at $28 \pm 2^{\circ} \mathrm{C}$ in a $1 \mathrm{~L}$ flask in the dark and static conditions. After 28 days of incubation time, the fungal mycelia were separated from the supernatant and grinded in liquid $\mathrm{N}_{2}$. Supernatant and grinded mycelia were combined and extracted with twice the volume of ethyl acetate. The extracted organic phase was concentrated using a rotary evaporator (IKA RV 10 D S96) at $40^{\circ} \mathrm{C}$. The residues were carefully weighed and solubilized in methanol $(1 \mathrm{ml})$ and stored at $4{ }^{\circ} \mathrm{C}$ until further use.

\section{Assessment of In Vitro Cytotoxic Activity of Fungal Extracts by MTT Assay}

The cytotoxicity of the extracts was examined by the MTT assay by determining the viability of cells (Kuriakose et al., 2014). Briefly, HeLa cells were grown and maintained in DMEM medium and supplemented with $10 \%$ fetal bovine serum, $100 \mathrm{U} / \mathrm{ml}$ penicillin, $100 \mathrm{mg} / \mathrm{ml}$ streptomycin, and 1\% (v/v) GlutaMAX and incubated at $37^{\circ} \mathrm{C}$ in a $5 \% \mathrm{CO}_{2}$ of the humidified chamber. $1 \times 10^{4}$ cells $/ \mathrm{ml}$ HeLa cells in $100 \mu \mathrm{L}$ of DMEM were seeded in 96-well plates and incubated for $24 \mathrm{~h}$. Thereafter, the cells were treated with fungal crude extracts at a range of concentrations $(10,50,100$, and $200 \mu \mathrm{g} /$ $\mathrm{ml})$ in $100 \mu \mathrm{L}$ media and incubated for $48 \mathrm{~h}$, respectively. At the end of $48 \mathrm{~h}, 10 \mu \mathrm{L}$ of MTT reagent $(5 \mathrm{mg} / \mathrm{ml})$ was added to each well. After $2 \mathrm{~h}$ of incubation at $37^{\circ} \mathrm{C}$, the plates were emptied and MTT reagent was removed. To the each well, dimethyl sulfoxide $(100 \mu \mathrm{L})$ was added and then the absorbance was measured at $595 \mathrm{~nm}$ wavelength with an ELISA reader Infinite M2000 Pro $^{\mathrm{TM}}$ (Tecan, Crailsheim, Germany) (Kumari et al., 2018). The $\mathrm{IC}_{50}$ values were calculated for each fungal extract. All the assays were performed in triplicates and results were presented as mean \pm SD. Aspergillus sp. extract demonstrated the highest cytotoxicity and was, hence, chosen for further investigation.

\section{Optimization of Incubation Interval, Extraction Solvent, and Growth Medium for Extraction of Cytotoxic Secondary Metabolites From Aspergillus sp.}

In the first study, the growth curve of Aspergillus sp. was plotted. The fungus was inoculated in $300 \mathrm{ml}$ of PDB and harvested after 
different time points $(7,14,21,28$, and 35 days), and extracted with ethyl acetate. After optimization of incubation time, the organic solvent was optimized for increased extraction of anticancer secondary metabolites. In the second study, the endophytic fungus grown in PDB for 21 days was extracted with equal volume of different solvents of varying polarities viz. hexane, chloroform, dichloromethane, and ethyl acetate. . In the third study, nine liquid media were investigated for finding the suitable medium for growth and production of cytotoxic secondary metabolites viz. czapek yeast extract broth (CZB), malt extract broth (MEB), yeast extract phosphate broth (YEP), yeast malt extract broth (YME), potato dextrose broth (PDB), Goose and Tschessch broth (GTB), Leonine broth (LEB), Sabouraud broth (SDB), and Gauce medium (GA1) (Pu et al., 2013; Pan et al., 2016; Kumari et al., 2018) (Supplementary Table S1).

Each culture medium was inoculated with two agar discs ( $5 \mathrm{~mm}$ diameter) containing fungal mycelium, and incubated for 21 days at $28{ }^{\circ} \mathrm{C}$ under static conditions. The liquid cultures were carried out in $1 \mathrm{~L}$ Erlenmeyer flasks containing $100 \mathrm{ml}$ medium. Each culture was grown in triplicate. At the end of the incubation period, the mycelial weight was recorded by filtering the contents of each culture flask through a preweighed Whatman no. 3 filter paper that was preweighed using Buchner funnel. The fungal mycelium was washed thrice with sterile deionized water. The fungal mycelium dry weight was measured after overnight drying in a hot air oven. As described earlier, the total culture fungal extract was prepared and investigated for cytotoxicity by the MTT assay.

\section{Analysis of Volatile Metabolites by Gas Chromatography-Mass Spectroscopy}

The cytotoxic Aspergillus sp. ethyl acetate extract (ASE), was subjected to GC-MS analysis to investigate the presence of volatile metabolites. Previous reports have suggested that, GC-MS was used to analyze secondary metabolites from different organisms/ sources, including bacteria (Mohamad et al., 2018), fungi (Gomathi et al., 2015; Kumari et al., 2018), and plants (Gomathi et al., 2015). High Performance Liquid Chromatography (HPLC) will again serve the same purpose. Many ethnopharmocology studies have also applied other spectroscopic techniques than HPLC to assess the chemical constituents of an extract (Ghuman et al., 2016; Mai et al., 2016; Savage et al., 2019).

The analysis of GC-MS was done in an Agilent GC-MS apparatus (GC: 7890A; MSD5975C) with fused silica HP-5 capillary column $(30-0.25 \mathrm{~mm}$, ID, thickness of film is $0.25 \mu \mathrm{m}$ ), was directly coupled to a single quadrupole MS. The Kavitha and Savithri (2017) protocol for chromatographic separation of the metabolites was followed. All the detected compounds were identified by mass spectral database search using the National Institute of Standards and Technology (NIST).

\section{Determination of Cytotoxic Activity of ASE on Different Cancer Cell Lines by MTT Assay} Cytotoxicity induced by ASE on a variety of human cancer cell lines viz. HeLa (cervical adenocarcinoma), MCF-7 (breast adenocarcinoma), Hep G2 (hepatocellular carcinoma), A549 (lung carcinoma), A-431 (epidermoid carcinoma) and LN-229 (glioblastoma), and on non-cancer human embryonic kidney cell line (HEK 293T) was determined by the MTT assay after $48 \mathrm{~h}$ of treatment, as described earlier (Kuriakose et al., 2014). HeLa cells treated with $1 \mathrm{mM}$ doxorubicin for $16 \mathrm{~h}$ served as a positive control.

\section{Propidium Iodide Staining and Cell Viability Analysis by Flow Cytometry}

To identify the percentage of viable cells upon treatment with ASE, a membrane impermeable dye that is generally excluded from viable cells, propidium iodide was used (Kuriakose et al., 2016). Cells stained with propidium iodide were counted as dead cells and unstained cells were counted as live/viable cells.

Briefly, the cancer cell line HeLa and a non-cancer cell line, CHO cells $\left(1 \times 10^{4}\right.$ cells $\left./ \mathrm{ml}\right)$ were seeded in a 24 -well culture plate and treated with a range of concentrations of ASE $(10,25,50 \mu \mathrm{g} /$ $\mathrm{ml}$ ) for $48 \mathrm{~h}$. After $48 \mathrm{~h}$, the cells were trypsinized, followed by PBS washes were given twice and PI $(1 \mu \mathrm{g} / \mathrm{ml})$ was added prior to data acquisition. Untreated healthy cells served as negative control, doxorubicin $(1 \mathrm{mM})$ treated cells for $16 \mathrm{~h}$ served as a positive control. BD FACSVerse (Becton Dickinson, United States) was used for data acquisition and BD FACSDiva $^{\mathrm{TM}}$ software was used to analyze the data.

\section{Quantification of Apoptosis Using Acridine Orange/Propidium lodide Double Staining}

The quantification of ASE-induced apoptotic HeLa cells was done by using acridine orange (AO) and propidium Iodide (PI) double staining. Each well of the six-well plate was seeded with $10^{4} \mathrm{HeLa}$ cells approximately, on poly-L-Lysine $(0.01 \%)$-coated coverslips (24 mm). After $24 \mathrm{~h}$ of incubation, cells were subjected to 10, 25, and $50 \mu \mathrm{g} / \mathrm{ml}$ concentrations of ASE for $48 \mathrm{~h}$. After $48 \mathrm{~h}$, PBS is used for washing cells twice and then kept for staining for 2-3 min with a mixture of AO/PI $(1 \mathrm{mg} / \mathrm{ml})$. Under a confocal microscope (Epi-fluorescence Olympus DSU, Japan), these cells were surveyed for the presence of cell death by apoptosis (Zahedifard et al., 2015). Cells without treatment served as control.

\section{Determination of Mitochondrial Membrane Potential and Reactive Oxygen Species}

The change in mitochondrial membrane potential (MMP or $\Delta \Psi \mathrm{m})$ after ASE treatment was determined by JC-1 staining as illustrated previously (Dhayanithy et al., 2019). As described earlier, HeLa cells $\left(1 \times 10^{4}\right.$ cells $)$ were seeded in 24 -well plates and incubated for $24 \mathrm{~h}$. On the following day, different concentrations on ASE were added to the medium. After $24 \mathrm{~h}$ of the addition of fungal extract, JC- 1 dye $(2.5 \mu \mathrm{g} / \mathrm{ml})$ was added to each well and incubated for $15 \mathrm{~min}$ at $37 \mathrm{C}$ in the $\mathrm{CO}_{2}$ incubator in dark conditions. Subsequently, the cells were trypsinized and washed with PBS. This was followed by an immediate analysis by flow cytometry at an excitation 
wavelength of $488 \mathrm{~nm}$ and emission wavelengths $530 \mathrm{~nm}$ and $590 \mathrm{~nm}$. BD FACSVerse (Becton Dickinson, United States) was used for data acquisition and BD FACSSuite software was used to analyze the data. JC-1 monomers showed the emission around $530 \mathrm{~nm}$ (grezen fluorescence), while that of J aggregates exhibit at $590 \mathrm{~nm}$ (orange-red fluorescence). Cells treated with 2, 4Dinitrophenol $(2,4$-DNP) served as positive control, while the untreated cells served as a negative control.

ROS generation was measured in HeLa cells after treatment with ASE using DCFH-DA staining. Briefly, after $24 \mathrm{~h}$ of incubation of HeLa cells $\left(1 \times 10^{4}\right.$ cells $)$ in 24 -well plates, the cells were treated with a range of ASE concentrations for $24 \mathrm{~h}$. To confirm the production of ROS, ASE $(50 \mu \mathrm{g} / \mathrm{ml})$ was added with a ROS scavenger; $\mathrm{N}$-acetyl-L-cysteine (NAC) at $5 \mathrm{mM}$ concentration for $1 \mathrm{~h}$ (Badisa et al., 2015). In order to detect the production of ROS, HeLa cells after treatment were harvested, washed twice with PBS, and stained with $50 \mu \mathrm{M}$ of DCFH-DA for a period of $15 \mathrm{~min}$ in dark at $37 \mathrm{C}$. Cell treated with $\mathrm{H}_{2} \mathrm{O}_{2}$ $(800 \mu \mathrm{M})$ served as positive control and untreated cells served as negative control. The fluorescence generated as a result of oxidation after hydrolysis of DCFH-DA to DCFH was quantified using flow cytometry around $500 \mathrm{~nm}$. BD FACSVerse (Becton Dickinson, United States) was used for data acquisition and BD FACSuite software was used to analyze the data.

\section{Measurement of Apoptosis by Phosphatidylserine Externalization by Annexin V-FITC/PI Staining}

The exposure of phosphatidylserine (PS) is known to be a transitional occurrence through cellular apoptosis and stirring after mitochondrial membrane depolarization, nevertheless, before DNA fragmentation. Annexin $\mathrm{V}^{+} / \mathrm{PI}^{-}$cells were quantified as early stage of apoptosis. However, Annexin $\mathrm{V}^{+} / \mathrm{PI}^{+}$cells signify a late phase of apoptosis. The percentage of apoptotic HeLa cells treated with ASE was stained using the fluorescein isothiocyanate (FITC)-conjugated annexin V/Propidium Iodide (PI) Assay Kit, according to the manufacturer's protocol (eBioscienceTM Annexin V; Invitrogen, San Diego, United States) and further quantified using flow cytometry. Briefly, HeLa cells $\left(1 \times 10^{5}\right.$ cells) were seeded in 24well plates in complete DMEM media and were allowed to adhere at $37 \mathrm{C}$ in a $\mathrm{CO}_{2}$ incubator. After $24 \mathrm{~h}$ of incubation, the cells were treated with different concentrations $(10,25$, and $50 \mu \mathrm{g} / \mathrm{ml})$ ASE for $24 \mathrm{~h}$. The cells were trypsinized, washed with PBS, and stained with $1 \mu \mathrm{L}$ of Annexin V-FITC stain, with or without PI in an annexinbinding buffer, according to the manufacturer's instructions. Cells were analyzed by flow cytometry after $15 \mathrm{~min}$ of incubation at room temperature in the dark at excitation/emission of $488 / 520 \mathrm{~nm}$ for Annexin-FITC and 540/630 nm for PI. BD FACSVerse (Becton Dickinson, United States) was used for data acquisition and BD FACSuite software was used to analyze the data.

\section{Cell Cycle Analysis}

The effect of ASE on the cell cycle progression in HeLa cells was probed by adapting protocols from Zheng et al., 2016 with some modifications. HeLa cells $\left(1 \times 10^{5}\right.$ cells $)$ were seeded in 12 -well plates in a complete DMEM media and allowed to adhere at $37 \mathrm{C}$ in a $\mathrm{CO}_{2}$ incubator. After $24 \mathrm{~h}$ of incubation, the cells were treated with different concentrations of ASE for $24 \mathrm{~h}$; harvested, washed twice with PBS, and 70\% ethanol fixation was done, kept overnight at $-20 \mathrm{C}$. After incubation, the fixed cells were centrifuged at 10,000 rpm for $10 \mathrm{~min}$, washed twice with PBS, and then treated with RNase $(5 \mu \mathrm{g} / \mathrm{ml})$ for $4 \mathrm{~h}$ at $37^{\circ} \mathrm{C}$. The cells were then stained with PI for $30 \mathrm{~min}$ prior to the acquisition of data by flow cytometry at $500 \mathrm{~nm}$. BD FACSVerse (Becton Dickinson, United States of America) was used for data acquisition and BD FACSuite software was used to analyze the data. For each sample, 10,000 events were acquired. Untreated cells served as control.

\section{Caspase 3/7/10 Fluorometric Analysis}

Briefly, $1 \times 10^{6} \mathrm{HeLa}$ cells were seeded in six-well plate. ASE was added with the increasing concentrations $(25,50$, and $100 \mu \mathrm{g} / \mathrm{ml})$, whereas untreated cells served as uninduced control. After $48 \mathrm{~h}$ of treatment, cells were centrifuged at 2,000 rpm, washed with PBS, and the cell pellet was stored at $-20^{\circ} \mathrm{C}$.

The Caspase 3, 7, and 10 Apoptosis fluorometric Assay Kit (G-Biosciences) was used to estimate the apoptotic activity of ASE on HeLa cells. Manufacturer's instructions were followed to perform the assay. Briefly, the cell pellet was resuspended in $100 \mu \mathrm{L}$ of lysis buffer and freeze/thawed for 4 to 5 times to obtain cell lysate. For each fluorometric reaction, $50 \mu \mathrm{L}$ of cell lysate, $50 \mu \mathrm{L}$ of $2 \mathrm{X}$ assay buffer containing $1 \mathrm{mM}$ of DTT and $5 \mu \mathrm{L}$ of $1 \mathrm{mM}$ substrate "Aspartic acid-Glutamic acid-Valine-Aspartic acid-7-amino-4trifluoromethyl coumarin" (DEVD-AFC) was added.

Caspases cleaved DEVD-AFC to release the peptide (DEVD) and fluorescent molecule (AFC), which can be read at emission $375 \mathrm{~nm}$ and excitation $530 \mathrm{~nm}$. Untreated cells served as uninduced control containing $100 \mu \mathrm{L}$ of assay buffer and $5 \mu \mathrm{L}$ substrate AFC-DEVD. Two hundred $\mu \mathrm{M}$ of Z-VAD-FMK (Broad spectrum apoptosis inhibitor) added to $100 \mu \mathrm{g} / \mathrm{ml} \mathrm{ASE-treated}$ cell lysate served as a negative control.

The reaction was carried out in 96-well plate. After taking readings at " $t=0$," reaction was incubated at $37^{\circ} \mathrm{C}$ for $60 \mathrm{~min}$. The change in fluorescence absorbance at time point " 0 " minutes and time point " 60 " minutes was plotted in the graph.

\section{Statistical Analysis}

All the experiments were performed in triplicate and quantitative variables were represented in terms of mean \pm S.D. in histograms. For statistical significance, mean $\pm \mathrm{SD}$ of all groups were compared and analysis of variance (ANOVA) was performed using a statistical package, SPSS 16.0 (SPSS Inc, Chicago, IL, United States). The probability of a $p$-value of $\leq 0.05$ was taken to indicate statistical significance. Further, the Duncan's multiple range test (DMRT) was used to identify the pairs of groups where the mean were significantly different at $\alpha=0.05$.

\section{RESULTS AND DISCUSSION}

\section{Four Endophytic Fungi Were Isolated and Identified From a Marine Alga, S. muticum}

The fungal isolates were identified using a combination of classical and molecular taxonomy approach. In classical 
TABLE 1 | Identification of endophytic fungi isolated from brown alga "Sargassum muticum."

Strain number (endophyte)
Colony morphology ${ }^{a}$
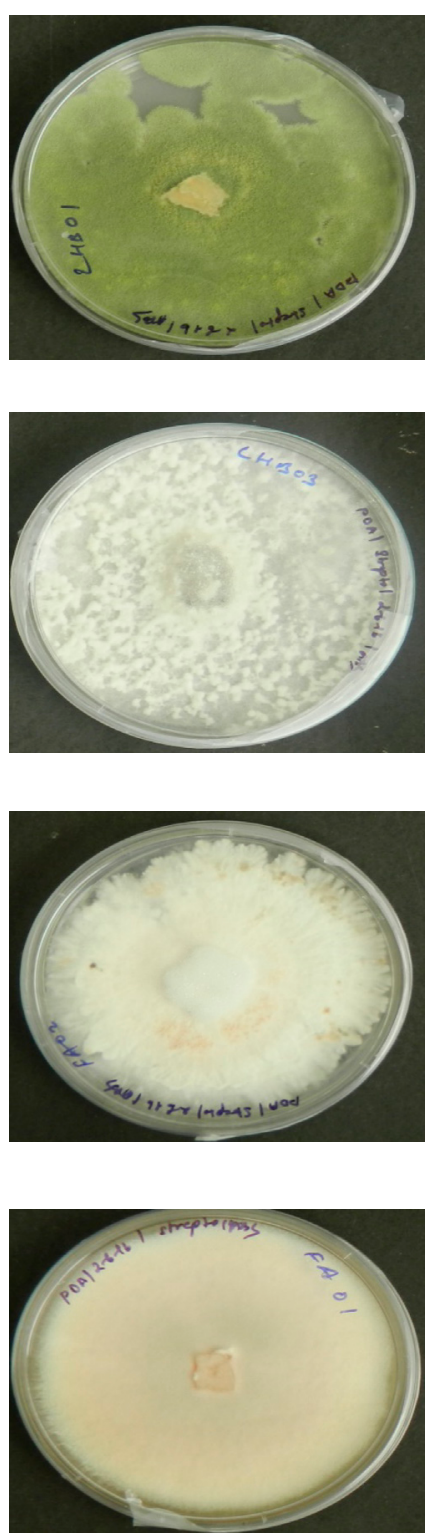

Fungal strains identified ${ }^{\mathbf{b}}$

Aspergillus sp.

GenBank accession number

MG807064

Nigrospora sphaerica

MF457920

Talaromyces purpureogenum

MG807063

Talaromyces stipitatus

MF457921 taxonomy approach, the fungi were identified based on their culture morphology. Four fungal endophytes recovered from S. muticum exhibited characteristic colony morphology on PDA (Table 1). Aspergillus sp. was characterized by the greenish-white growth of mycelia, while the reverse side was yellowish-orange to light peach in color. $N$. sphaerica demonstrated characteristics rapidly growing floccose white colonies, which turned black with age (Wang et al., 2017). T. purpureogenus was characterized by gray velutinous colonies, while T. stipitatus was identified by irregular white colonies, which turned gray with age. DNA fragments of around
500-600 bp (ITS region) were amplified and sequenced for all four isolates. The ITS sequences were compared with the GenBank sequences using a BLAST search and deposited in GenBank database (Table 1). Molecular characterization of these endophytes were done based on ITS rDNA sequence analysis. The isolated strains were morphologically and taxonomically identified as Aspergillus sp., $T$. purpureogenus, N. sphaerica, and T. stipitatus. The partial identified sequences have been submitted to GenBank with accession numbers MG807064, MG807063, MF457920, and MF457921, respectively (Table $\mathbf{1}$ ). 


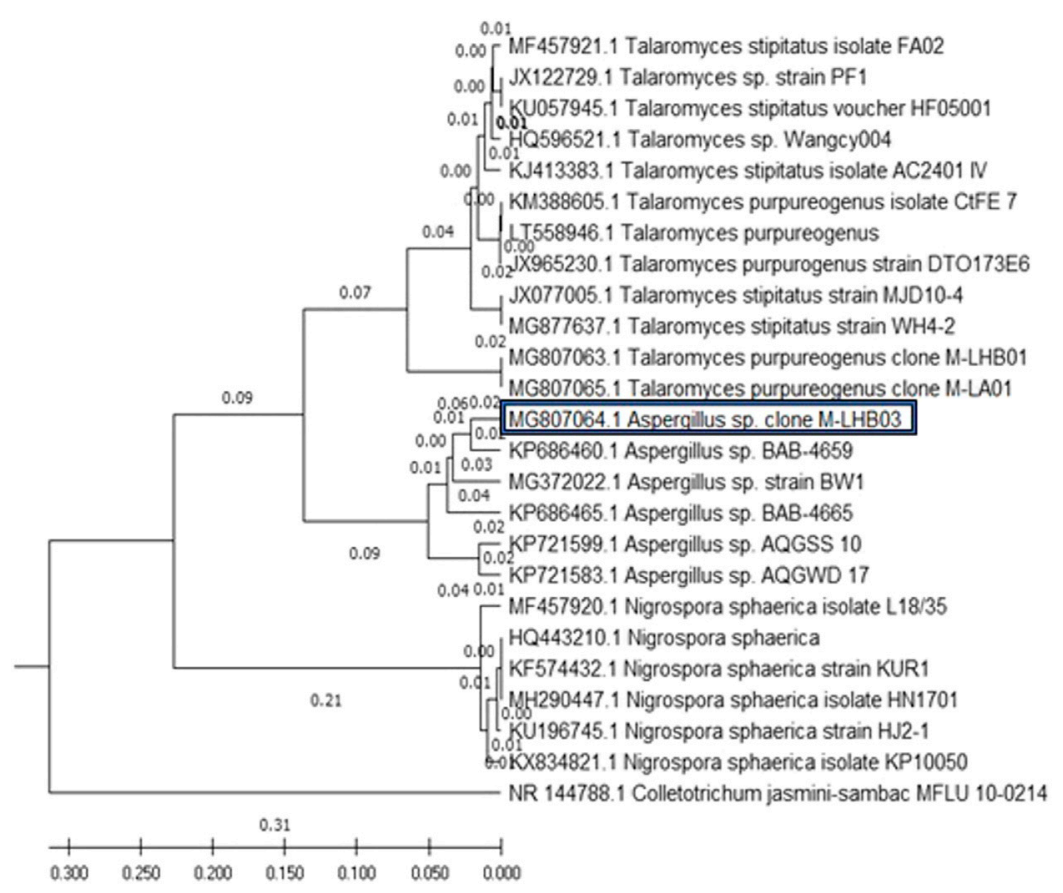

FIGURE 1 | Phylogenetic relationship of four endophytic fungal isolates derived from S. muticum marine alga, sampled from the Kovalam Coast, was constructed using MEGAX software by the UPGMA method. The endophytic fungi clade with fungi of their respective genus and stand separate from the outgroup Colletotrichum jasmine-sambac.

The evolutionary history of the five endophytic fungi was constructed using the MEGA X software and deduced using the UPGMA method. Figure 1 shows the optimal tree with the sum of branch length $=1.30066823$. The tree was drawn to scale, with branch lengths, as represented next to the branches, in the same units as those of the evolutionary distances used to deduce the phylogenetic tree. The maximum composite likelihood method was used to compute the evolutionary distances in the tree. It was observed that all the four endophytic fungi clade with endophytes of their respective genus and stand separate from the outgroup Colletotrichum jasmine-sambac (Katoch et al., 2017; Minarni Artika et al., 2017; Kumar et al., 2018).

\section{The Crude Extracts of Isolated Endophytic Fungi Demonstrated Cytotoxic Activity on Cancer Cells}

The four fungi were grown for 35 days in PDB to test for their cytotoxicity, and extraction of fungal mycelium together with the culture filtrate was done with ethyl acetate. The cytotoxicity of the dried fungal extract was investigated on HeLa cells. There was a dosedependent response when four different concentrations $(10,50,100$, and $200 \mu \mathrm{g} / \mathrm{ml}$ ) were tested for each sample. The results of the cytotoxic activity of the fungal crude extracts are shown in Figure 2. The $\mathrm{IC}_{50}$ values of Aspergillus sp. and T. stipitatus extracts for HeLa cell were $30 \pm$ 1 and $117 \pm 2 \mu \mathrm{g} / \mathrm{ml}$, respectively, while for $T$. purpureogenus and $N$. sphaerica extracts, the $\mathrm{IC}_{50}$ values were $\geq 200 \mu \mathrm{g} / \mathrm{ml}$ for HeLa cells. Among the four endophytic isolates screened, Aspergillus sp. demonstrated maximum cytotoxic activity on HeLa cell line after $48 \mathrm{~h}$ of treatment in a concentration-dependent manner, and hence chosen for further studies (Figure 2). Endophytic fungi residing in pharmacologically important algae may also gain specific attributes or contribute to their host (Gomes et al., 2015; Mayer et al., 2020) to adapt the marine niche, resulting in the production of bioactive compounds.

Penicillium and Aspergillus sp. have earlier been reported as endophytes of the marine alga Sargassum (Flewelling et al., 2015), but their role as cytotoxic agents have not been elucidated. Earlier, Miao et al., 2014 reported anticancer activity of endophytic Aspergillus wenti isolated from Sargassum fusiforme.

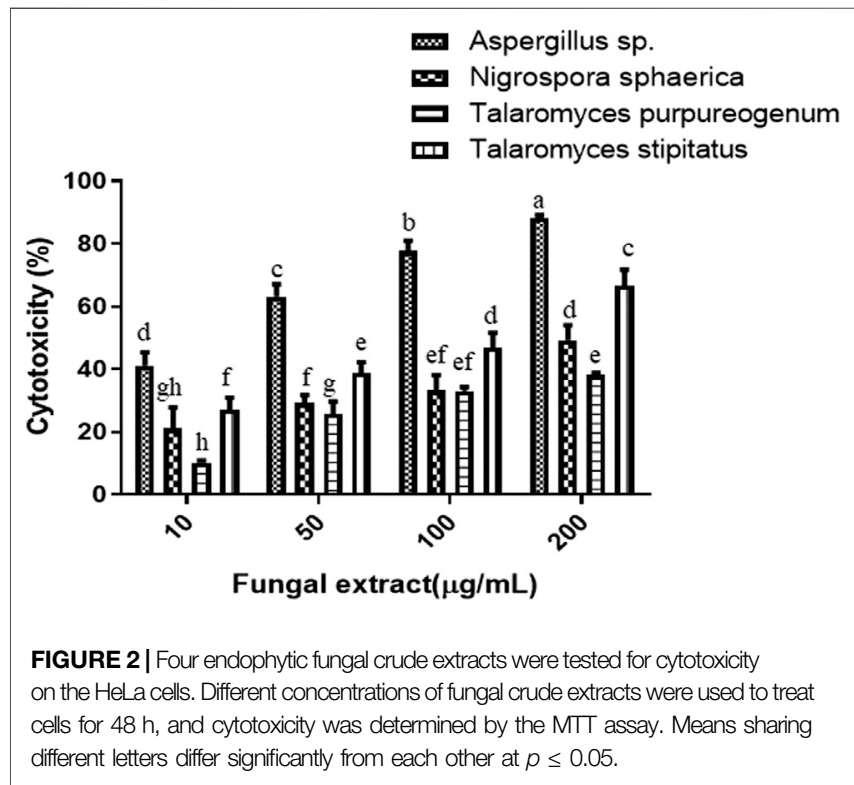



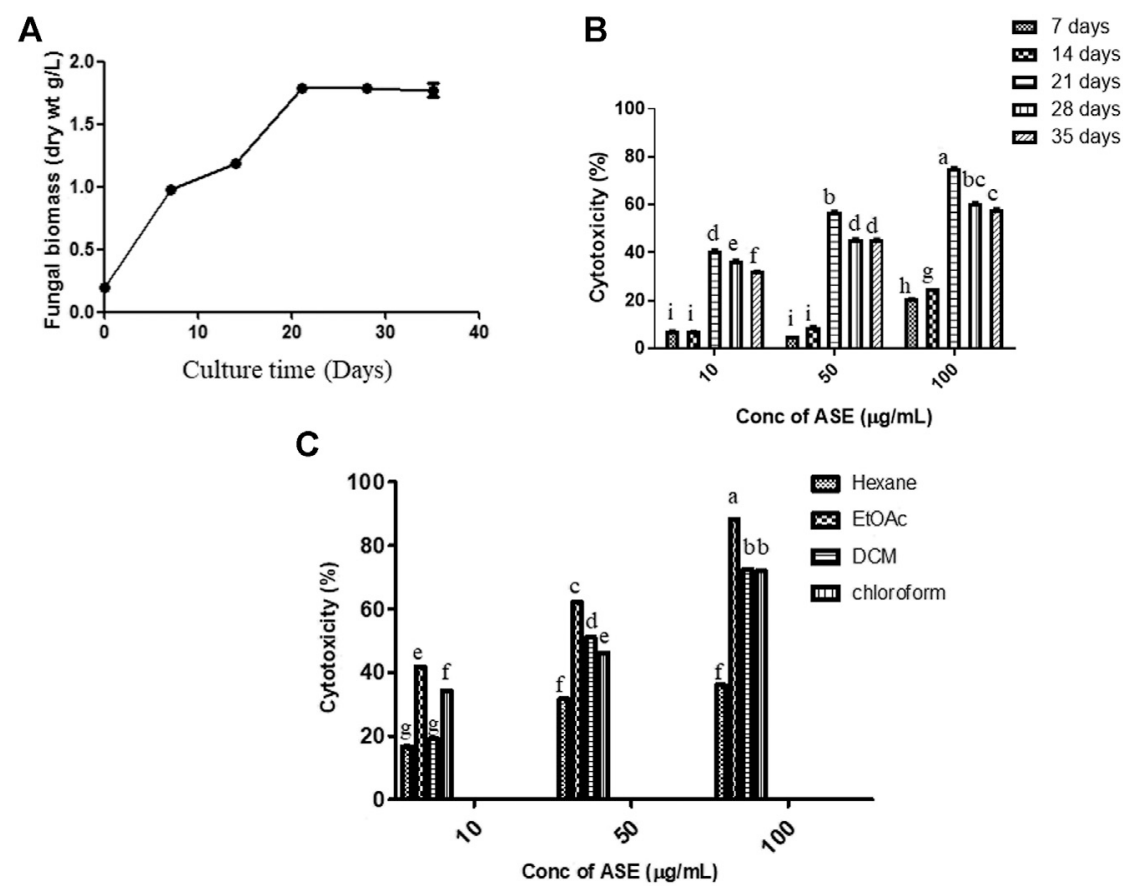

FIGURE 3 | Time course of production of (A) biomass, (B) cytotoxic secondary metabolites in PDB culture of Aspergillus sp., and (C) effect of the different solvent extract on cytotoxicity. The fungus was grown for the different time intervals in PDB. The mycelium was harvested, dried, and weighed as described in Materials and Methods. cytotoxic effect of the extracts on HeLa cells was determined by the MTT assay. Means sharing different letters differ significantly from each other at $p \leq 0.05$.
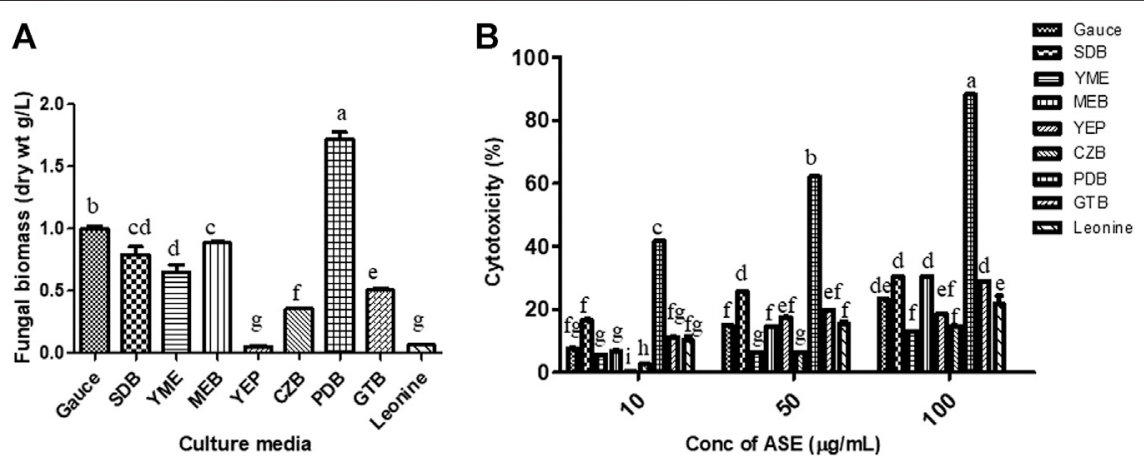

FIGURE 4 | (A) Biomass. (B) Aspergillus sp. was grown in different media for the production of cytotoxic secondary metabolites. Aspergillus sp. grew in different culture media; the mycelium was separated, dried, and weighed as described in Materials and Methods. Cytotoxicity of ASE was tested on HeLa cells by the MTT assay. Means sharing different letters differ significantly from each other at $p \leq 0.05$.

\section{GROWTH PARAMETERS OPTIMIZATION RESULTED IN INCREASE IN THE PRODUCTION OF CYTOTOXIC SECONDARY METABOLITES FROM TOTAL CULTURE EXTRACT OF ASPERGILLUS SP.}

\section{Growth Curve Optimization}

Fungal isolate was grown in PDB for different time intervals of 7 , $14,21,28$, and 35 days under stationary condition. Maximum dry biomass $(1.7 \mathrm{~g} / \mathrm{L})$ and cytotoxic activity were obtained after 21 days of inoculation in total culture ethyl acetate fungal extract (Figures 3A,B). Bioactive compounds present in the fungal extract are generally secondary metabolites which were produced in stationary phase of growth curve, which was reached after 21 days of incubation with this extract (Bourgaud et al., 2001; Kebede et al., 2017; Navarri et al., 2017). The results well corroborated with the highest cytotoxicity obtained after 21 days of incubation (Figure 3B), which was also the time period for highest production of secondary metabolites. Further, since production was carried out in batch process, there is also nutrient depletion, with Carbon and $\mathrm{N}$-source limitation, inhibiting the increase in cytotoxic activity after 21 days of incubation. 


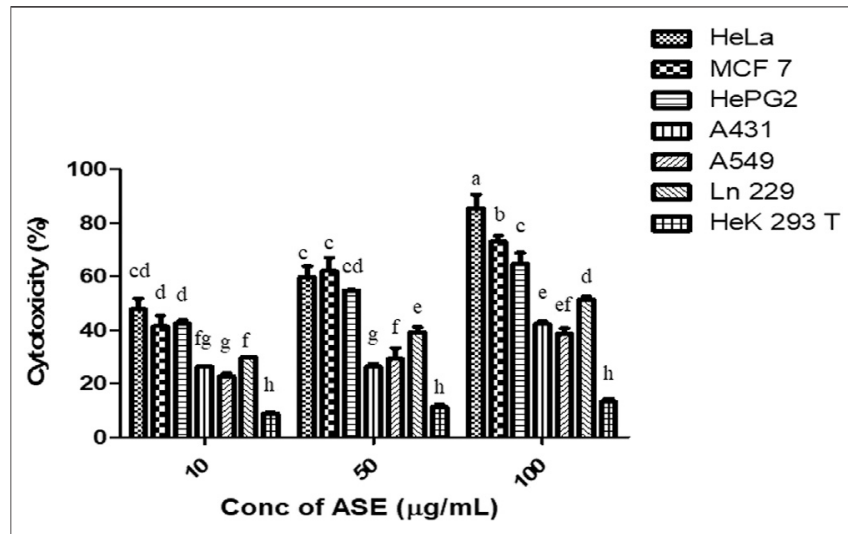

FIGURE 5 | Cytotoxicity of ASE on multiple human cancer cell lines. Different concentrations of ASE were used to treat cells for $48 \mathrm{~h}$, and cytotoxicity was examined by the MTT assay. Means sharing different letters differ significantly from each other at $p \leq 0.05$.

\section{Solvent Optimization}

After optimization of incubation time, different solvent systems viz. hexane, ethyl acetate, dichloromethane, and chloroform were used for extracting cytotoxic secondary metabolites from the total culture fungal extract grown in PDB for 21 days (Figure 3C). Maximum cytotoxicity was obtained in ethyl acetate extract of total culture fungal extract, followed by dichloromethane. After optimization of different growth parameters, the $\mathrm{IC}_{50}$ value obtained was $21.35 \pm 0.9 \mu \mathrm{g} / \mathrm{ml}$ against HeLa cell line. The polarity of metabolite is a characteristic that must be considered during extraction optimization (Haque et al., 2007). Maximum activity in ethyl acetate extract demonstrates semipolar nature of bioactive compounds responsible for cytotoxic activity.

\section{Media Optimization}

To find the optimum culture medium for the production of maximum biomass and the cytotoxic secondary metabolites, Aspergillus sp. was grown in nine different growth media, namely, czapek yeast extract broth (CZB), malt extract broth (MEB), yeast extract phosphate broth (YEP), yeast malt extract broth (YME), potato dextrose broth (PDB), Goose and tschessch broth (GTB), Leonine broth (LEB), sabouraud broth (SDB), and Gauce medium (GA1). Aspergillus sp. was grown for 21 days in abovementioned media, and the total culture was extracted with ethyl acetate, which was further evaluated for their cytotoxic activity. Among the nine media used, maximum biomass was obtained in PDB (1.7 g/L), followed by Gauce medium, MEB, and SDB (Figure 4A). Maximum cytotoxicity was observed in ASE obtained from PDB after 21 days of inoculation, followed by $\mathrm{MEB}, \mathrm{SDB}$, and CZB (Figure 4B). Media are a complex source of all the nutritional requirements of fungus and its manipulation will result in higher or lower production of cytotoxic compounds (Xu, 2015; Al-ansari et al., 2020). The different combination of carbon, nitrogen, growth supplements, and $\mathrm{pH}$ can significantly alter the production of desired secondary metabolites responsible for the cytotoxic activity. Understanding and exploiting the endophytes of ethnopharmacologically important algae, especially marine algae which have been used since ages may allow the discovery and sustainable production of the desired novel product.

The results demonstrated that all the different extracts of Aspergills sp. in different parameters (time, solvent and media) exhibited some cytotoxicity against HeLa cells, but ethyl acetate extract grown in PDB showed significantly higher cytotoxicity; hence, this extract (ASE) was used for further work.

\section{ASE Demonstrated Cytotoxicity on Multiple Human Cancer Cell Lines}

To test the broad-spectrum cytotoxicity of ASE, it was evaluated for cytotoxicity in vitro against six human cancer cell lines, HeLa (cervical adenocarcinoma), MCF-7 (breast adenocarcinoma), Hep G2 (hepatocellular carcinoma), A549 (lung carcinoma), A-431 (skin/ epidermis carcinoma) and LN229 (glioblastoma), and HEK 293T (normal human embryonic kidney cell line) by the MTT assay. ASE exhibited a different degree of cytotoxicity toward these cell lines in a dose-dependent manner (Figure 5). HeLa cells showed maximum cytotoxicity with $\mathrm{IC}_{50}$ value of $24 \pm 2 \mu \mathrm{g} / \mathrm{ml}$, followed by MCF-7 and Hep G2 with $\mathrm{IC}_{50}$ values of $32.0 \pm 2.3 \mu \mathrm{g} / \mathrm{ml}$ and $33.0 \pm 2.3 \mu \mathrm{g} / \mathrm{ml}$, respectively. The ASE showed moderate cytotoxicity on A549, A431 , and LN229 with an $\mathrm{IC}_{50}$ value of $166.6 \pm 1.4,155.0 \pm 1.3$, and $94.8 \pm 2.2 \mu \mathrm{g} / \mathrm{ml}$, respectively. Many natural products can target a range of cancer cell lines, making them a potential candidate for novel drug discovery or enhancing the potential of existing drugs (Shakeri et al., 2018; Spradlin et al., 2019).

The ASE did not show cytotoxicity on HEK 293T non-cancerous human embryonic kidney cell line cells, indicating that ASE is not toxic to non-cancerous cells. One of the most important criteria for testing the safety of cytotoxic drug is their cytotoxic effect on noncancer cell lines. Efficient cytotoxic drugs implant different mechanisms on cancer or non-cancer cells, making cancerous cells more susceptible toward the drug (Navya et al., 2019). Krishnamurthy et al., 2018 characterized an ankaflavin from Penicillium aculeatum and found significantly less cytotoxicity on HEK 293T and CHO cell lines. HeLa cells were used for further studies.

\section{Secondary Metabolites Were Analyzed by Gas Chromatography-Mass Spectroscopy}

A total of 71 compounds were identified after GC-MS analysis of the total culture fungal extract (Table 2). Many peaks were not identified using GC-MS database, suggesting the existence of novel compounds which can also be responsible for cumulative cytotoxicity of ASE. 1,2-dihydro-2,2,4-trimethylquinoline; 2,4Bis(1,1-dimethyl ethyl)phenol; cetene; indole; hexahydro-3-(2methyl propyl); 7,9-di-tert-butyl-1-oxaspiro(4,5)deca-6,9-diene2,8-dione; pyrrolo[1,2-a]pyrazine-1,4-dione; hexahydro-3-(2methyl propyl); behenic alcohol; 1-docosene; n-hexadecanoic acid; and 1-nonadecene were some of the major compounds (Figure 6).

Quinoline and indole act as precursors for construction motif of many novel anticancer drugs (Wang et al., 2015; Jain et al., 2016). 2,4-bis(1,1-dimethylethyl) phenol, a metabolite produced by seaweed-associated bacteria, Gracilaria gracilis, was shown to inhibit quorum sensing by disrupting biofilm formation in the uropathogenic Serratia marcescens (Padmavathi et al., 2014). 
TABLE 2 | Quantification of metabolites present in the ethyl acetate total culture extract.

Metabolites

Relative concentration (\%)

3.829 Isophorone

$0.024739 \pm 0.0214$

4.39 Dehydromevalonic lactone

4.659 Benzenemethanol, a-methyl-, acetate (1-Phenylethyl acetate)

4.869 Allene

5.185 2,5-Diamino-6-methyl-4-pyrimidinol

5.268 Cyclopentanecarboxamide, N-[2-(2-methylphenoxy) ethyl]

6.027 Hydroquinone

7.61 1,2-Benzenedicarboxylic acid

8.411 Indole

8.411 4-Thiepanone, 5-hydroxy-3,3,6,6-tetramethyl

8.865 Benzaldehyde, 4-hydroxy

8.895 Nicotinonitrile, 2-mercapto-5,6-dimethyl

8.928 Propanoic acid, 3-chloro-, 4-formylphenyl ester

$8.98 \quad 2$-Hydroxyethyl salicylate

9.348 Phenol, 2-propyl

10.268 1-Tetradecene

10.245 Acetic acid, (2,4-xylyl)

12.494 4H-Pyran-4-one, 5-hydroxy-2-(hydroxymethyl)

13.215 Quinoline, 1,2-dihydro-2,2,4-trimethyl

13.241 Benzene, (1-methyl-2-cyclopropen-1-yl)

13.966 Pentanamide, 2-amino-4-methyl-, (S)

14.638 2,5-Cyclohexadiene-1,4-dione, 2,6-bis(1,1-dimethylethyl)

15.4757 2H-Pyran-2-one, 5,6-dihydro-6-pentyl

16.004 3-Furanacetic acid, 4-hexyl-2,5-dihydro-2,5-dioxo

16.075 Hexathiane

18.319 Phenol, 2,4-bis(1,1-dimethylethyl)

21.718 Pentaerythritol tetraacetate

25.404 4-Ethoxy-3-anisaldehyde

27.392 4-Trifluoroacetoxyhexadecane

27.449 Cetene

27.506 7-Tetradecene, (E)-

30.629 Benzenesulfonamide, 2-methyl

37.441 Benzenesulfonamide, 4-methyl

58.002 2-Dodecylcyclobutanone

57.694 1-(3,3,3-Trifluoro-2-hydroxypropyl) piperidine

76.726 1-Decanol, 2-hexyl

123.608 Benzothiazole, 2-(2-hydroxyethylthio)

125.498 Pyrrolo [1,2-a] pyrazine-1,4-dione, hexahydro-3-(2-methylpropyl)

125.269 7,9-Di-tert-butyl-1-oxaspiro (4,5)deca-6,9-diene-2,8-dione

125.315 Pyrrolo [1,2-a] pyrazine-1,4-dione, hexahydro-3-(2-methylpropyl)

127.521 Hexadecane, 1,1-bis(dodecyloxy)

127.555 Dibutyl phthalate

128.671 Behenic alcohol

128.701 1-Docosene

129.326 2-Oxabicyclo [4.2.0]oct-4-en-3-one, rel-(1R,6S,7S,8S)-5-methoxy-8-(4-methoxy-2-oxo-2H-pyran-6-yl)-7-(4ethylphenyl)-1-[(E)-2-(4-ethylphenyl)ethenyl]

$129.331 \quad \mathrm{n}$-Hexadecanoic acid

129.396 7-[2-(Ethoxycarbonyl)-3a,5ß-dimethoxycyclopentyl-1]-heptanoic acid, ethyl ester

129.914 1-Nonadecene

129.834 Behenic alcohol

132.75 Fluoranthene

132.752 Pyrene

133.556 cis-10-Heptadecenoic acid

134.549 3,7,11,15-Tetramethyl-2-hexadecen-1-ol

135.349 E-8-Octadecacen-1-ol acetate

136.106 10-Undecen-1-ol

136.667 Dodecane, 1-iodo

144.356 1-Docosene

138.27 2-Ethyl-1-dodecanol

139.533 1,11-Dodecadiene

$142.191 \quad 2-M e t h y l-1$-octadecene

142.866 Octadecanoic acid

145.377 Behenic alcohol

149.738 Tetradecane

$0.089144 \pm 0.78$

$0.007911 \pm 0.06$

$0.002334 \pm 0.02$

$0.041644 \pm 0.06$

$0.0256 \pm 0.01$

$0.038706 \pm 0.003$

$0.029598 \pm 0.214$

$0.118424 \pm 0.002$

$0.32368 \pm 0.002$

$0.468704 \pm 0.004$

$0.276363 \pm 0.00 .3$

$0.024365 \pm 0.008$

$0.208081 \pm 0.005$

$0.231031 \pm 0.001$

$0.215665 \pm 0.004$

$0.105721 \pm 0.06$

$0.057381 \pm 0.05$

$0.46619 \pm 0.01$

$0.096929 \pm 0.01$

$0.223893 \pm 0.008$

$0.17996 \pm 0.007$

$0.010647 \pm 0.02$

$0.493393 \pm 0.008$

$0.139576 \pm 0.02$

$16.23937 \pm 0.008$

$0.205363 \pm 0.005$

$0.096244 \pm 0.001$

$0.006329 \pm 0.004$

$0.312184 \pm 0.06$

$0.00283 \pm 0.05$

$0.017773 \pm 0.004$

$0.0041 \pm 0.145$

$0.293613 \pm 0.002$

$0.072175 \pm 0.004$

$0.008129 \pm 0.002$

$0.151434 \pm 0.03$

$2.502151 \pm 0.01$

$2.681396 \pm 0.03$

$1.132229 \pm 0.04$

$0.01824 \pm 0.0254$

$0.265049 \pm 0.005$

$14.00159 \pm 0.02$

$7.517438 \pm 0.03$

$2.23088 \pm 0.008$

$5.130184 \pm 0.339$

$0.023503 \pm 0.1$

$15.90127 \pm 0.004$

$0.824719 \pm 0.005$

$0.032659 \pm 0.654$

$0.014283 \pm 0.006$

$0.824719 \pm 0.0215$

$0.019086 \pm 0.009$

$0.149983 \pm 0.006$

$0.00408 \pm 0.001$

$0.011406 \pm 0.339$

$0.165953 \pm 0.19$

$0.023392 \pm 0.02$

$0.010846 \pm 0.001$

$0.378232 \pm 0.002$

$0.339807 \pm 0.02$

$22.31756 \pm 0.007$

$0.007353 \pm 0.01$

(Continued on following page)

Frontiers in Pharmacology | www.frontiersin.org 
TABLE 2 | (Continued) Quantification of metabolites present in the ethyl acetate total culture extract.

\begin{tabular}{|c|c|c|c|}
\hline S. no & RT (min) & Metabolites & Relative concentration (\%) \\
\hline 64 & 149.784 & 4,4-Dipropylheptane & $0.002693 \pm 0.002$ \\
\hline 65 & 154.351 & 1-Heptene & $0.003067 \pm 0.02$ \\
\hline 66 & 161.002 & Cyclotetracosane & $0.043148 \pm 0.08$ \\
\hline 67 & 161.161 & n-Tetracosanol-1 & $2.719422 \pm 0.08$ \\
\hline 68 & 169.467 & 2-Butyl-1-decene & $0.014163 \pm 0.01$ \\
\hline 69 & 173.972 & 2,3,4-Trimethyl-1-pentanol & $0.004776 \pm 0.002$ \\
\hline 70 & 179.549 & Tetracosyl heptafluorobutyrate & $0.005889 \pm 0.08$ \\
\hline 71 & 179.654 & 1-Tricosanol & $0.029586 \pm 0.001$ \\
\hline
\end{tabular}

Aspergillus sp. by GC-MS analysis. Values are the mean $\pm S D$ of three independent experiments.

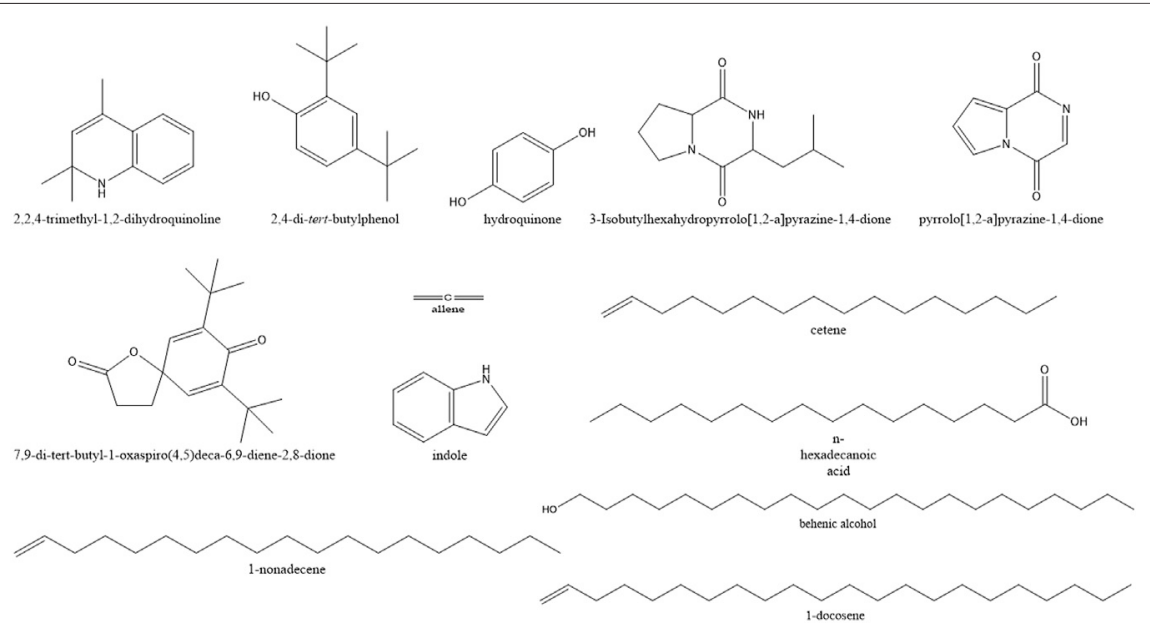

FIGURE 6 | Structures of the major compounds detected in GC-MS analysis of ethyl acetate extract of Aspergillus sp.

Hexadecanoic acid isolated from leaves of Kigelia pinnata showed the cytotoxic effect on HCT-116 (human colorectal cancer) by DNA topoisomerase I interaction (Ravi and Krishnan, 2017). Allene and hydroquinone were also produced from the fungal extract which has been used as antiviral and anticancer compounds against melanoma cells, respectively (HoffmannRöder and Krause, 2004; Byeon et al., 2018).

Many compounds produced by endophytic isolate Aspergillus sp. from $S$. muticum were found to have biological activities. Fungal endophytes isolated from ethnopharmacologically important plant and algae can become an inexpensive alternative to natural products.

\section{TREATMENT OF ASE RESULTED IN INTERFERENCE WITH CELL VIABILITY, PROGRESSION IN CELL CYCLE, AND CELL NUCLEAR MORPHOLOGY IN HELA CELLS}

\section{PI Live/Dead Analysis Revealed the Concentration-Dependent Cytotoxicity of ASE in HeLa Cells}

To evaluate the cytotoxic effect of ASE on HeLa cells, PI-based cell live/dead staining was employed. The PI live/dead assay is a reliable method to quantify the dead cells, where PI is able to stain nuclear material only when the membrane is compromised (Kumari et al., 2018; Kamat et al., 2020b). HeLa cells were treated with indicated concentrations of ASE (10, 25, and $50 \mu \mathrm{g} / \mathrm{ml}$ ), stained with PI, and flow cytometry analysis was done (Supplementary Figure S1). The PI live/dead assay was also performed with a non-cancer $\mathrm{CHO}$ cell line. Figure 7A showed an increase in dead cell population with a dosage-dependent effect on viability after $48 \mathrm{~h}$ treatment on HeLa cells, while $\mathrm{CHO}$ cell line was not affected by increased concentration of the drug. The percentage dead cell population were found to be $38 \pm 0.9,50 \pm 1.2$, and $60 \pm 1.3 \mu \mathrm{g} / \mathrm{ml}$ for HeLa cells, respectively, when treated with 10,25 , and $50 \mu \mathrm{g} / \mathrm{ml}$ of ASE. These observations confirm cytotoxicity of ASE in HeLa cells, while they prove to be non-cytotoxic on non-cancer $\mathrm{CHO}$ cell line. Doxorubicin showed a significant cytotoxicity on both $\mathrm{HeLa}$ and $\mathrm{CHO}$ cell lines. Natural products are known to be cytotoxic on cancer cell lines, while having no inhibitory action on normal cells on similar concentration. Artemisinin, a repurposed cytotoxic natural product derived from Artemisia annua L. shows potent cytotoxicity against retinoblastoma cell lines, while it shows low cytotoxicity on normal retina cell lines (Lichota and Gwozdzinski, 2018). The changes in the cell surface, microtubule remodeling, dysfunctional ROS scavenging system, cell cycle, and DNA repair mechanisms are some of the parameters which are significantly altered in cancer cells as compared 


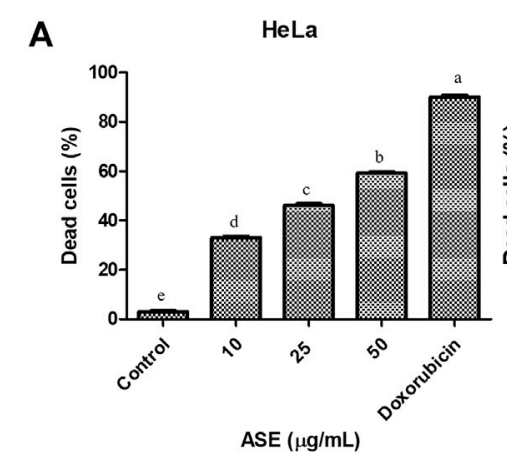

B

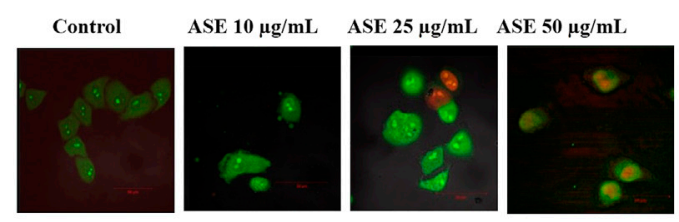

C
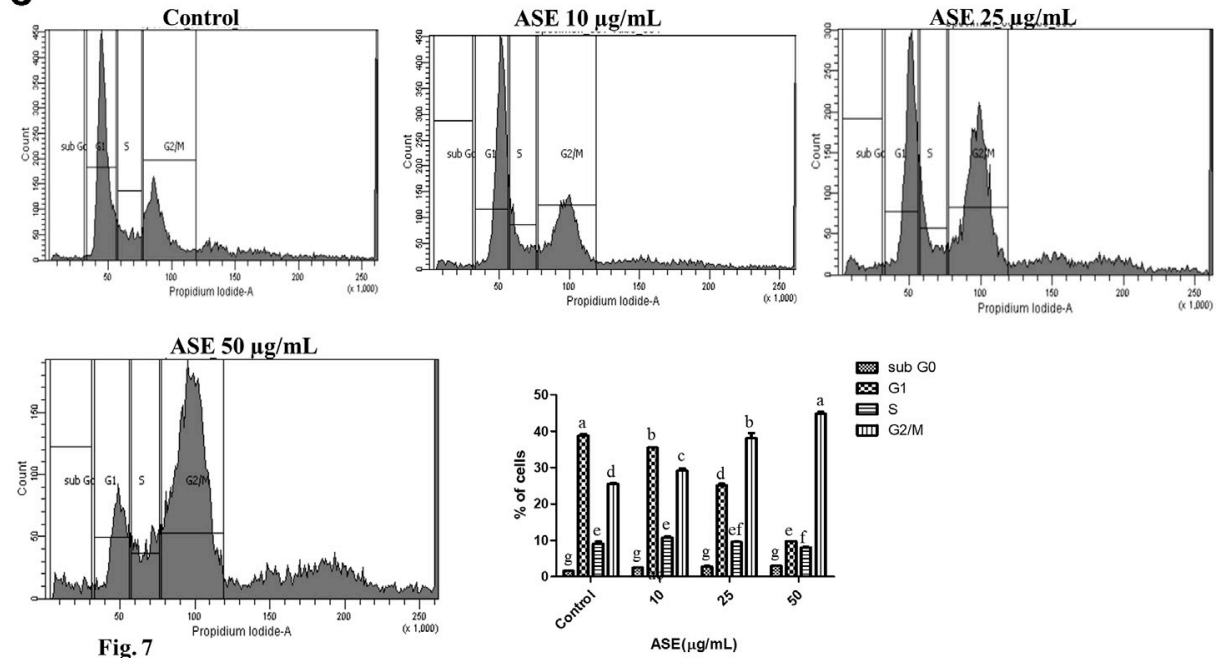

FIGURE 7 | Effects of ASE on HeLa cell line including the viability of cells, cell cycle distribution, and cellular morphology. Treatment of cells with different concentrations of ASE (A) PI-based live/dead staining by flow cytometry analysis upon treatment with ASE. The percentage of dead cells was shown in the ASE-treated HeLa cells and noncancer $\mathrm{CHO}$ cells in a bar diagram. (B) Fluorescent micrographs of apoptotic morphological changes in HeLa cells treated with ASE followed by dual staining with AO/PI. Apoptotic/dead cells emit red fluorescence, while live/viable cells emit green fluorescence. The arrows indicate apoptotic cells. (C) The percentage of cells in each cell cycle phase was evaluated by propidium iodide-based staining by flow cytometry in the HeLa cells after treatment with ASE. The distribution of cells at different phases of cell cycle progression following treatment with ASE represented in a bar diagram. Means sharing different letters differ significantly from each other at $p \leq 0.05$.

to normal cells, leading to different mode of action of natural products and different cytotoxicity on the normal and cancer cells (Borys et al., 2020). Doxorubicin, on the other hand is a potent anticancer drug, but has been known for several side effects, including non-targeted cytotoxicity (Ibiyeye et al., 2019). The cytotoxic compounds isolated from the extract of ASE can help in reducing the side effects of chemotherapy.

\section{Change in Nuclear Morphology of HeLa Cells was Shown by AO/PI Staining}

$\mathrm{AO}$ is a cell permeable fluorescent dye which stains nuclear DNA in both live and dead cells, whereas PI is another fluorescent dye that stains nuclear DNA in only those cells that have lost their membrane integrity (Astuti et al., 2016). AO/PI staining is a common morphology-based method to differentiate between normal, early apoptotic, and late apoptotic cells. In order to study nuclear morphological changes associated with in HeLa cells upon treatment with ASE, acridine orange and propidium iodide dyes were used for fluorescence microscopy. As shown in Figure $\mathbf{7 B}$, untreated cells showed light green fluorescence while apoptotic cells showed bright green fluorescence, indicating chromatin condensation and membrane blebbing in ASEtreated cells. Propidium iodide binding and labeling to DNA, indicated by red color established that the late apoptosis stage affected by the ASE membrane blebbing is a key feature of early apoptosis which results from caspase-mediated activation of ROCK I (Coleman et al., 2001). Similarly, different stages of 


\section{A}

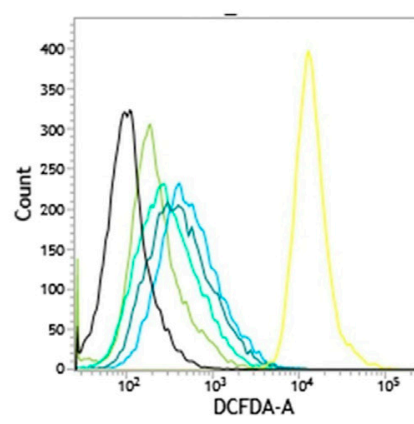

B
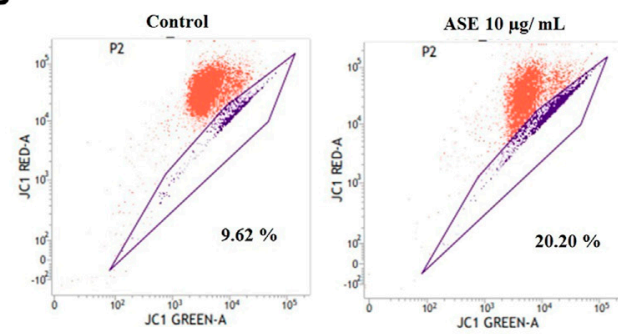

ASE $50 \mu \mathrm{g} / \mathrm{mL}$
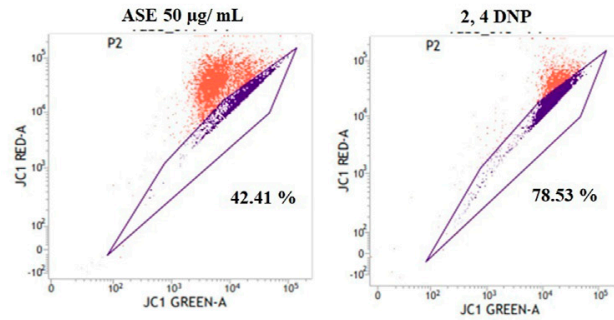

ASE $10 \mu \mathrm{g} / \mathrm{mL}$

C

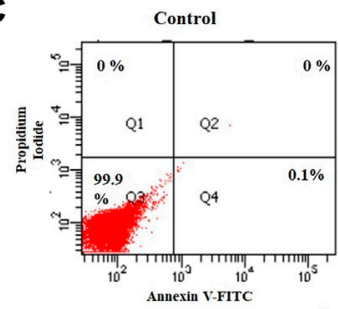

Control

$\square$ ASE $10 \mathrm{mg} / \mathrm{mL}$

$\square$ ASE $50 \mathrm{mg} / \mathrm{mL}$

$\square$ ASE $50 \mathrm{mg} / \mathrm{mL}+\mathrm{NAC}$

$\square \mathrm{H}_{2} \mathrm{O}_{2}$

$\square \mathrm{H}_{2}$
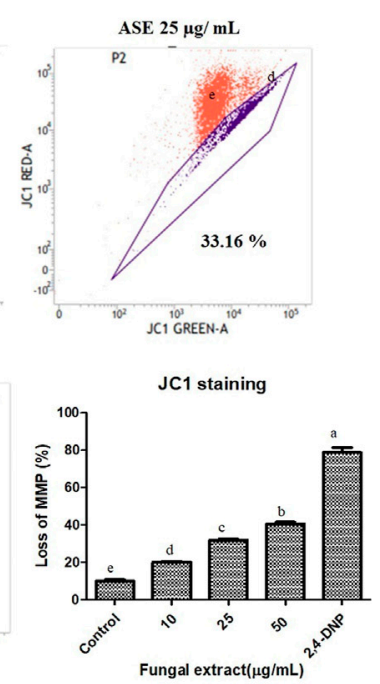

ASE $25 \mu \mathrm{g} / \mathrm{mL}$

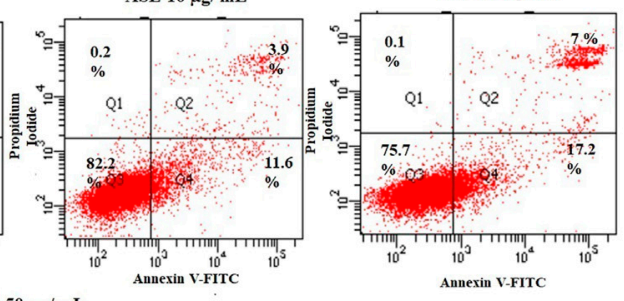

ASE $50 \mu \mathrm{g} / \mathrm{mL}$
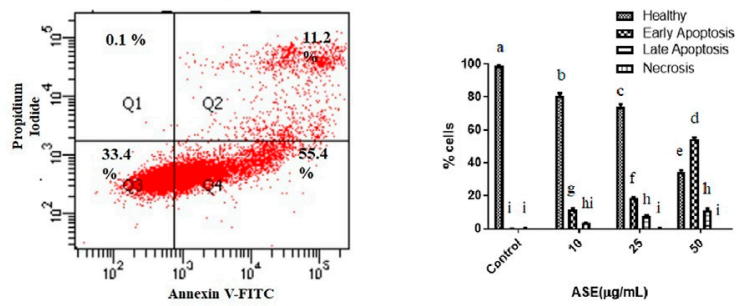

FIGURE 8 | Effect of ASE on HeLa cell apoptosis. (A) Effect of ASE on ROS production. Intracellular ROS was detected by DCFH-DA dye after cells were treated with ASE by flow cytometry. Overlay graph presents as fold values using graphs compared with control. (B) Effect of ASE on mitochondrial membrane depolarization. Cells treatment was with different concentrations of ASE for 24 h and then they were stained with JC-1 which detects depolarization of mitochondrial membrane by using flow cytometry. The percentage of ASE-treated cells showing the increase in mitochondrial membrane depolarization in a dosage-dependent manner was shown in a bar diagram; cells treated with 2,4-dinitrophenol (2,4-DNP) served as positive control. (C) Apoptosis (PS externalization) determined by propidium iodide uptake and binding Annexin $\mathrm{V}$ to phosphatidylserine of by flow cytometry analysis. It shows four group of cells, cells that were negative for Annexin- $\mathrm{V}$ and propidium iodide were normal healthy (Quadrant 3); cells that were positive to Annexin-V were early apoptotic (Quadrant 4); cells positive both Annexin V and PI were late apoptotic (Quadrant 2); and cells that only stained with PI were necrotic or dead (Quadrant 1). ASE with an indicative concentration was treated against HeLa cells for $24 \mathrm{~h}$. The distribution of normal healthy, early apoptotic, late apoptotic, and necrotic cell populations was represented in a bar diagram. Means sharing different letters differ significantly from each other at $p \leq 0.05 .9$. Effect of ASE on Caspase 3, 7, and 10 activity of Hela cells. Different concentrations of fungal crude extracts were treated to cells for $48 \mathrm{~h}$ and caspase 3, 7, 10 activity was determined by Caspase 3, 7,10 Apoptosis fluorometric Assay Kit. Means sharing different letters differ significantly from each other at $p$ $\leq 0.05$. 
chromatin condensation can reveal the different stages of apoptosis (Tone et al., 2007).

\section{G2/M Phase Cell Cycle Arrest was Observed After Treatment With ASE in the HeLa Cells}

To get an insight whether cytotoxicity induced by ASE, implicates changes in the progression of the cell cycle, cells in different stages of the cell cycle were analyzed by flow cytometry. As shown in Figure 7C, we observed a concentration-dependent increase in accumulation of cells in $\mathrm{G} 2 / \mathrm{M}$ phase after $48 \mathrm{~h}$ of treatment in ASE-treated cells at 10,25 , and $50 \mu \mathrm{g} / \mathrm{ml}$ and there was a decrease in G1 and S phase cells. These results show ASE causes arrest at a G2/M phase in cell cycle progression. The connection with the apoptosis and cell cycle arises from the multiple indications that cell cycle progression alteration may either block or trigger apoptosis (Pucci et al., 2000). Natural products are known to induce $\mathrm{G} 2 / \mathrm{M}$ phase arrest, thereby inducing apoptosis (Hnit et al., 2020; You et al., 2020). Astuti et al., (2016) observed apoptosis-mediated cell death by endophytic Aspergillus sp, isolated from Piper crocatum after inducing $S$ phase cell cycle arrest. Several reports support the involvement of apoptosis regulatory genes in cell cycle progression as well (Pucci et al., 2000; Wang et al., 2016).

\section{THE MECHANISM INVOLVED IN THE INDUCTION OF APOPTOSIS BY ASE IN THE HELA CELLS DCFH-DA Staining Detected Production of ROS After Treatment of ASE in HeLa Cells}

ROS production, a primary signal for apoptosis and shown to be involved in the mitochondrial-driven apoptosis (Yang et al., 2016), was assesses by DCFH-DA staining. It is a ROS specific fluorescent redox probe which gets oxidized to DCF (dichlorofluorescein) in the presence of ROS (Kumari et al., 2018). Supplementary Figure S2, showed the percentage of ROS positive cells $(26.96,49.64$, and $80.57 \%)$ after HeLa cells were treated with increasing concentration of ASE (10, 25, and $50 \mu \mathrm{g} / \mathrm{ml}$ ). Cells without treatment showed $2.5-3 \%$ cells served as negative control, $800 \mathrm{mM} \mathrm{H} \mathrm{H}_{2}$ for $15 \mathrm{~min}$ showed $96.21 \%$ served as positive control, After ASE $50 \mu \mathrm{g} / \mathrm{ml}$ treatment for $48 \mathrm{~h}$ media was replaced with $5 \mathrm{mMN}$-acetyl cysteine (NAC) for $1 \mathrm{~h}$ showed $66.57 \%$ served as another control. In the overlay graph showed in Figure $\mathbf{8 A}$, ASE showed an increase in intracellular ROS production in a dose-dependent manner. After treatment with NAC, a ROS scavenger, the ROS production by ASE $(50 \mu \mathrm{g} / \mathrm{ml})$ reduced from 80 to $66 \%$. NAC is a common antioxidant used to assess the ROS generation capabilities and ROS related antiproliferative roles of cytotoxic drugs (Khan et al., 2020). The results indicated that ROS generation induced by ASE in the HeLa cells contributes to apoptosis. Generation of ROS and high oxidative stress is one of the mechanisms; many potent drugs including taxol employ to exhibit multiple genetic alterations to initiate apoptosis in tumor cells via ROS-dependent mitochondrial dysfunction (Trachootham et al., 2009; Wu et al., 2017).

\section{Mitochondrial Membrane Depolarization Was Observed After JC 1 Staining}

It is well known that mitochondria, a primary source of ROS generation contributes toward the apoptosis of cancer cells (Kumari et al., 2018). Mitochondrial membrane depolarization was assessed by cyanine dye JC one which facilitates discrimination of polarized and depolarized mitochondria because formation of the red aggregates when concentrated in polarized mitochondria in response to their higher membrane potential than the normally green fluorescent dye (Perelman et al., 2012).

We tested the effect of ASE on the depolarization of mitochondrial membrane in HeLa cells (Supplementary Figure S3). In healthy cells with intact mitochondria, JC-1 molecules aggregates to form a polymer-emitting orange-red fluorescence, whereas, in cells with depolarized mitochondria, JC-1 monomers emits green fluorescence in the cytosol (Cossarizza and Salvioli, 2001). After HeLa cells were treated with ASE, a shift in mitochondria with JC1 staining red to green fluorescence was observed in a concentrationdependent manner (Figure 8B). An increased in the mitochondrial depolarization up to $20.20,33.16$, and $42.41 \%$ were observed when HeLa cells were treated with 10,25 , and $50 \mu \mathrm{g} / \mathrm{ml}$ of ASE for $24 \mathrm{~h}$, respectively in a dose-dependent manner. Control cells without ASE treatment showed 8-10\%, cells treated with 2,4-Dinitrophenol (2,4DNP) served as positive control showed $78.53 \%$ loss of mitochondrial membrane potential. This suggests ASE-induced mitochondrial depolarization. Excessive generation of ROS may trigger mitochondrial depolarization leading to the intrinsic mitochondriamediated pathway of apoptosis. Dandan et al., 2016 have also demonstrated hesperetin-induced ROS production activating the mitochondrial-mediated apoptosis in esophageal cancer cells.

\section{Annexin V-FITC/PI Staining Showed Induction of Apoptosis After ASE Treatment in the HeLa Cells}

To further evaluate the mechanism of ASE-mediated cell death in HeLa cells, phosphatidylserine (PS) externalization was measured using FITC-labeled annexin V (Koopman et al., 1994; Martin et al., 1995). PS externalization on the plasma membrane in apoptotic cells is an intermediate event, occurring after mitochondrial membrane depolarization but before DNA fragmentation during cellular apoptosis (Suzuki et al., 2013). Annexin-V FITC/propidium iodide-based flow cytometry was used to detect healthy cells, early, late apoptotic cells, or dead cells. Annexin V-FITC binds to phosphatidylserine (PS) present on the outer side of the cell membrane of apoptotic cells. In healthy cells, PS remains on cytosolic side of plasma membrane making the cells negative to Annexin V-FITC (Singh et al., 2016). We conducted this assay to investigate the apoptosis-inducing potential of the ASE in HeLa cells. As indicated by FACS analysis, HeLa cells treated with the low concentration $(10 \mu \mathrm{g} /$ $\mathrm{ml}$ ) of ASE exhibited $12 \%$ of cells in early apoptosis stage with $3.5 \%$ in late apoptosis. As the concentration increased, more cells 


\section{Caspase 3,7, 10 fluorometric assay}

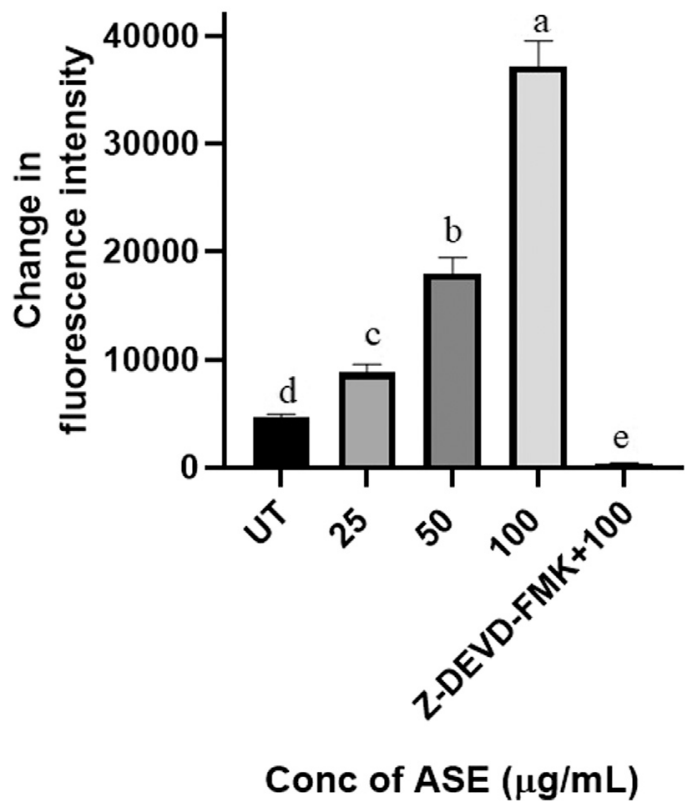

FIGURE 9 | Effect of ASE on caspase 3, 7, and 10 activity of Hela cells. Different concentrations of fungal crude extracts were treated to cells for $48 \mathrm{~h}$, and caspase 3, 7, and 10 activity was determined by caspase 3, 7, and 10 Apoptosis Fluorometric Assay Kit. Means sharing different letters differ significantly from each other at $p \leq 0.05$.

shifted to early and late apoptosis in a dose-dependent manner (Figure 8C). The mechanism of ASE-induced cell death was by apoptosis. Apoptosis is one of the most common cell death mechanisms implied by natural products to induce cell death in cancer cells (Diederich, 2020; Balusamy et al., 2020). Endophytic Aspergillus sp. isolated from diverse host plants and related hosts have also shown apoptosis-mediated cell death on multiple cancer cell lines (Yao et al., 2016; Uzma et al., 2018).

\section{Caspase 3, 7, and 10 Fluorometric Assay Indicated Apoptotic Cell Death in HeLa Cells After Treatment With ASE}

Upregulation of Caspase 3, 7, and 10 proteins demonstrates the progression of apoptosis, making them the key indicators of this phenomenon (Brentnall et al., 2013). Activation of caspase three and seven are the prime events in apoptosis which initiates a cascade of reaction, leading to programmed cell death in cancer cells (McComb et al., 2019). The results demonstrated the dosagedependent increase in fluorescence intensity, indicating activation of the caspase pathway in HeLa cells after treatment with different concentrations of ASE (Figure 9). Further, when apoptosis inhibitor Z-VAD-FMK was added to the cells treated with $100 \mu \mathrm{g} / \mathrm{ml}$ of ASE, a significant decrease in caspase activity was observed (Figure 9). The results clearly indicated the progression of cell death in treated HeLa cells by apoptosis.

\section{CONCLUSION}

Resistance to cancer cells is steadily increasing, and many clinically used anticancer drugs are no longer effective. There is a high demand for innovative lead compounds to develop novel drugs for the treatment of cancer. Marine algal-derived endophytic fungi attract attention as a source of potential anticancer compounds. In the current study, cytotoxicity studies of crude extracts of endophytic fungi isolated from seaweed $S$. muticum showed that they possess cytotoxic compounds. In most of the cancer cell types, the arrest in cell cycle progression induced apoptosis. Our experiments demonstrated that the ethyl acetate extract of Aspergillus sp. arrested HeLa cell line at the G2/M stage of cell cycle progression, leading to apoptosis in human cervical cancer cells. The induction of apoptosis was supported by ROS production, MMP depolarization, phosphatidylserine (PS) externalization, and activation of the caspase pathway (Scheme 1). Further work is needed on the bioassay-guided purification of the crude extract to determine the structure of the specific compounds responsible for the observed bioactivities.

\section{DATA AVAILABILITY STATEMENT}

The datasets presented in this study can be found in online repositories. The names of the repository/repositories and accession number(s) can be found in the article/Supplementary Material.

\section{AUTHOR CONTRIBUTIONS}

$\mathrm{CB}$ and SB conceived the idea. All experiments were performed and analyzed by ST, MK, and SK. The manuscript has been written by ST and MK, and critically examined by $\mathrm{CB}$ and SB.

\section{FUNDING}

This study was supported by grant (Ref. no. BT/PR/14569) from the Department of Biotechnology, Govt. of India, New Delhi.

\section{ACKNOWLEDGMENTS}

The authors thank FACS central facility, Division of Biological Sciences, Indian Institute of Science, Bengaluru. We also thank DBT-IISc partnership program, DST-FIST, and UGC Special Assistance Program for financial support. MK thanks UGC for awarding her D. S. Kothari Post-doctoral Fellowship (DSKPDF). ST thanks DBT for his SRF, and SK thanks UGC for her JRF. We also thank Late T. Ramasarma for correcting the manuscript in very short span of time.

\section{SUPPLEMENTARY MATERIAL}

The Supplementary Material for this article can be found online at: https://www.frontiersin.org/articles/10.3389/fphar.2021.542891/ full\#supplementary-material. 


\section{REFERENCES}

Al-Ansari, M., Kalaiyarasi, M., Almalki, M. A., and Vijayaraghavan, P. (2020). Optimization of medium components for the production of antimicrobial and anticancer secondary metabolites from Streptomyces sp. AS11 isolated from the marine environment. J. King Saud Univ-Sci. 32, 1993-1998. doi:10.1016/j.jksus. 2020.02.005

Alves, C., Silva, J., Pinteus, S., Gaspar, H., Alpoim, M. C., Botana, L. M., et al. (2018). From marine origin to therapeutics: the antitumor potential of marine algae-derived compounds. Front. Pharmacol. 6 (9), 777. doi:10.3389/fphar. 2018.00777

Astuti, P., Erden, W., Wahyono, W., Wahyuono, S., and Hertiani, T. (2016). Pyrophen produced by endophytic fungi Aspergillus sp isolated from piper crocatum ruiz and pav exhibits cytotoxic activity and induces $S$ phase Arrest in T47D breast cancer cells. Asian Pac. J. Cancer Prev. 17 (2), 615-618. doi:10. 7314/apjcp.2016.17.2.615

Badisa, R. B., Kumar, S. S., Mazzio, E., Haughbrook, R. D., Allen, J. R., Davidson, M. W., et al. (2015). N-acetyl cysteine mitigates the acute effects of cocaine-induced toxicity in astroglia-like cells. PLoS one 10 (1), e0114285. doi:10.1371/journal. pone. 0114285

Balunas, M. J., and Kinghorn, A. D. (2005). Drug discovery from medicinal plants. Life Sci. 78, 431-441. doi:10.1016/j.lfs.2005.09.012

Balusamy, S. R., Veerappan, K., Ranjan, A., Kim, Y.-J., Chellappan, D. K., Dua, K., et al. (2020). Phyllanthus emblica fruit extract attenuates lipid metabolism in 3T3-L1 adipocytes via activating apoptosis mediated cell death. Phytomed 66, 153129. doi:10.1016/j.phymed.2019.153129

Baracaldo, P., Bianchini, G., Cesare, A. D., Callieri, C., and Chrismas, N. A. M. (2019). Insights into the evolution of picocyanobacteria and phycoerythrin genes (mpeBA and cpeBA). Front. Microbiol. 10, 45. doi:10.3389/fmicb.2019.00045

Borys, F., Joachimiak, E., Krawczyk, H., and Fabczak, H. (2020). Intrinsic and extrinsic factors affecting microtubule dynamics in normal and cancer cells. Molecules 25 (16), 3705. doi:10.3390/molecules 25163705

Bourgaud, F., Gravot, A., Milesi, S., and Gontier, E. (2001). Production of plant secondary metabolites: a historical perspective. Plant Sci. 161, 839-851. doi:10. 1016/s0168-9452(01)00490-3

Brentnall, M., Rodriguez-Menocal, L., De Guevara, R., Cepero, E., and Boise, L. H. (2013). Caspase-9, caspase- 3 and caspase-7 have distinct roles during intrinsic apoptosis. BMC Cell Biol. 14, 32. doi:10.1186/1471-2121-14-32

Byeon, S., Yi, Y.-S., Lee, J., Yang, W., Kim, J., Kim, J., et al. (2018). Hydroquinone exhibits in vitro and in vivo anti-cancer activity in cancer cells and mice. Int. J. Mol. Sci. 19 (3), 903. doi:10.3390/ijms19030903

Choudhury, B., Kandimalla, R., Bharali, R., Monisha, J., Kunnumakara, A. B., Kalita, K., et al. (2016). Anti-cancer activity of Garcinia morella on T-cell murine lymphoma via apoptotic induction. Front. Pharmacol. 7, 3. doi:10.3389/ fphar.2016.00003

Coleman, M. L., Sahai, E. A., Yeo, M., Bosch, M., Dewar, A., and Olson, M. F. (2001). Membrane blebbing during apoptosis results from caspasemediated activation of ROCK I. Nat. Cell Biol. 3 (4), 339-345. doi:10. $1038 / 35070009$

Cossarizza, A., and Salvioli, S. (2001). Flow cytometric analysis ofmitochondrial membrane potential using JC-1. Curr. Protoc. Cytometry 13 (1), 9-14. doi:10. 1002/0471142956.cy0914s13

Dandan, W., Jixiang, Z., Jing, W., Jiao, L., Fei, L., and Dong, W. (2016). Hesperetin induces apoptosis of esophageal cancer cells via mitochondrial pathway mediated by the increased intracellular reactive oxygen species. Tumor Biol. 37 (3), 3451-3459. doi:10.1007/s13277-015-4176-6

Deshmukh, S. K., Prakash, V., and Ranja, N. (2018). Marine fungi: a source of potential anti-cancer compounds. Front. Microbiol. 8, 2536. doi:10.3389/fmicb. 2017.02536

Dhayanithy, G., Subban, K., and Chelliah, J. (2019). Diversity and biological activities of endophytic fungi associated with Catharanthus roseus. BMC Microbiol. 19, 22. doi:10.1186/s12866-019-1386-x

Diederich, M. (2020). Natural products target the hallmarks of chronic diseases. Biochem. Pharmacol. 173, 113828. doi:10.1016/j.bcp.2020.113828

Flewelling, A. J., Currie, A., Gray, C. A., and Johnson, J. A. (2015). Endophytes from marine macroalgae: promising sources of novel natural products. Curr. Sci. 10, 88-111. doi:10.1177/1934578x1501001003
Ghuman, S., Ncube, B., Finnie, J. F., McGaw, L. J., Coopoosamy, R. M., and Staden, J. V. (2016). Antimicrobial activity, phenolic content, and cytotoxicity of medicinal plant extracts used for treating dermatological diseases and wound healing in kwazulu-natal, South Africa. Front. Pharmacol. 7, 520. doi:10.3389/fphar.2016.00320

Gomathi, D., Kalaiselvi, M., Ravikumar, G., Devaki, K., and Uma, C. (2015). GCMS analysis of bioactive compounds from the whole plant ethanolic extract of Evolvulus alsinoides (L.) L. J. Food Sci. Technol. 52 (2), 1212-1217. doi:10.1007/ s13197-013-1105-9

Gomes, N., Lefranc, F., Kijjoa, A., and Kiss, R. (2015). Can some marine-derived fungal metabolites become actual anticancer agents? Mar. Drugs 13 (6), 3950-3991. doi:10.3390/md13063950

Haque, M. A., Hossain, M. S., Rahman, M., Rahman, M. R., Hossain, M. S., Mosihuzzaman, M., et al. (2007). Isolation of bioactive secondary metabolites from the endophytic fungus of Ocimum basilicum. Dhaka Univ. J. Pharm. Sci. 4 (2), 127-130. doi:10.3329/dujps.v4i2.215

Hnit, S. S. T., Yao, M., Xie, C., Ge, G., Bi, L., Jin, S., et al. (2020). Transcriptional regulation of $\mathrm{G} 2 / \mathrm{M}$ regulatory proteins and perturbation of G2/M Cell cycle transition by a traditional Chinese medicine recipe. J. Ethanopharmcol. 251, 112526. doi:10.1016/j.jep.2019.112526

Hoffmann Röder, A., and Krause, N. (2004). Synthesis and properties of allenic natural products and pharmaceuticals. Angew. Chem. Int. Ed. 43 (10), 1196-1216. doi:10.1002/anie.200300628

Ibiyeye, K. M., Nordin, N., Ajat, M., and Zuki, A. B. Z. (2019). Ultrastructural changes and antitumor effects of doxorubicin/thymoquinone-loaded $\mathrm{CaCO}_{3}$ nanoparticles on breast cancer cell line. Front. Oncol. 9, 599. doi:10.3389/fonc. 2019.00599

Jain, S., Chandra, V., Jain, P. K., Pathak, K., Pathak, D., and Vaidya, A. (2016). Comprehensive review on current developments of quinoline-based anticancer agents. Arabian J. Chem. 12 (8), 4920-4946. doi:10.1016/j.arabjc. 2016.10.009

Kaddes, A., Fauconnier, M.-L., Sassi, K., Nasraoui, B., and Jijakli, M. H. (2019). Endophytic fungal volatile compounds as solution for sustainable agriculture. Molecules 24, 1065. doi:10.3390/molecules24061065

Kamat, S., Kumari, M., Sajna, K. V., and Jayabaskaran, C. (2020b). Endophytic fungus, Chaetomium globosum, associated with marine green alga, a new source of Chrysin. Endophytic fungi of marine alga from Konkan coast, India -a rich source of bioactive material. Sci. Rep.. 10, 18726. doi:10.1038/s41598-020-72497-3

Kamat, S., Kumari, M., Taritla, S., and Jayabaskaran, C. (2020a). Endophytic fungi of marine alga from konkan coast, India-A rich source of bioactive material. Front. Mar. Sci. 7, 31. doi:10.3389/fmars.2020.00031

Karikas, G. A. (2010). Anticancer and chemopreventing natural products: some biochemical and therapeutic aspects. J. BUON 15 (4), 627-638.

Katoch, M., Phull, S., Vaid, S., and Singh, S. (2017). Diversity, Phylogeny, anticancer and antimicrobial potential of fungal endophytes associated with Monarda citriodora L. BMC Microbiol. 17 (1), 44. doi:10.1186/s12866-0170961-2

Kavitha, A., and Savithri, H. S. (2017). Biological significance of marine Actinobacteria of east coast of Andhra Pradesh, India. Front. Microbiol. 8, 1201. doi:10.3389/fmicb.2017.01201

Kebede, B., Wrigley, S., Prashar, A., Rahlff, J., Wolf, M., Reinshagen, J., et al. (2017). Establishing the secondary metabolite profile of the marine fungus: tolypocladium geodes sp. MF458 and subsequent optimisation of bioactive secondary metabolite production. Mar. Drugs 15 (4), 84. doi:10.3390/ md15040084

Khan, M., Maryam, A., Saleem, M. Z., Shakir, H. A., Qazi, J. I., Li, Y., et al. (2020). Brevilin A induces ROS-dependent apoptosis and suppresses STAT3 activation by direct binding in human lung cancer cells. J. Cancer 11 (13), 3725-3735. doi:10.7150/jca.40983

Kjer, J., Debbab, A., Aly, A. H., and Proksch, P. (2011). Methods for isolation of marine-derived endophytic fungi and their bioactive secondary products. Nat. Protoc. 5, 479-490. doi:10.1038/nprot.2009.233

Koopman, G., Reutelingsperger, C., Kuijten, G., Keehnen, R., Pals, S., and van Oers, M. (1994). Annexin V for flow cytometric detection of phosphatidylserine expression on B cells undergoing apoptosis. Blood 84 (5), 1415-1420. doi:10. 1182/blood.v84.5.1415.bloodjournal8451415

Krishnamurthy, S., Narasimha Murthy, K., and Thirumale, S. (2018). Characterization of ankaflavin from Penicillium aculeatum and its cytotoxic 
properties. Nat. Prod. Res. 34 (11), 1630-1635. doi:10.1080/14786419.2018. 1522633

Kumar, S., Stecher, G., Li, M., Knyaz, C., and Tamura, K. (2018). Mega X: molecular evolutionary genetics analysis across computing platforms. Mol. Biol. Evol. 35, 1547-1549. doi:10.1093/molbev/msy096

Kumari, M., Taritla, S., Sharma, A., and Jayabaskaran, C. (2018). Antiproliferative and antioxidative bioactive compounds in extracts of marine-derived endophytic fungus Talaromyces purpureogenus. Front. Microbiol. 9 (9), 1777. doi:10.3389/fmicb.2018.01777

Kuriakose, G. C., Palem, P. P. C., and Jayabaskaran, C. (2016). Fungal vincristine from Eutypella spp.-CrP14 isolated from Catharanthus roseus induces apoptosis in human squamous carcinoma cell line A-431. BMC Comp. Alt. Med. 16, 302. doi:10.1186/s12906-016-1299-2

Kuriakose, G. C., Singh, S., Rajvanshi, P. K., Surin, W. R., and Jayabaskaran, C. (2014). In vitro cytotoxicity and apoptosis induction in human cancer cells by culture extract of an endophytic Fusarium solani strain isolated from Datura metel L. Pharma. Analytica. Acta 5 (293), 2. doi:10.4172/2153-2435.1000293

Lichota, A., and Gwozdzinski, K. (2018). Anticancer activity of natural compounds from plant and marine environment. Int. J. Mol. Sci. 19 (11), 3533. doi:10.3390/ ijms19113533

Liu, L., Heinrich, M., Myers, S., and Dworjanyn, S. A. (2012). Towards a better understanding of medicinal uses of the brown seaweed Sargassum in Traditional Chinese Medicine: a phytochemical and pharmacological review. J. Ethnopharmacol. 142, 591-619. doi:10.1016/j.jep.2012.05.046

Mai, C. W., Yap, K. S. I., Kho, M. T., Ismail, N. H., Yusoff, K., Shaari, K., et al. (2016). Mechanisms underlying the anti-inflammatory effects of clinacanthus nutans lindau extracts: inhibition of cytokine production and toll-like receptor4 activation. Front. Pharmacol. 7, 7. doi:10.3389/fphar.2016.00007

Martin, S. J., Reutelingsperger, C. P., McGahon, A. J., Rader, J. A., van Schie, R. C., LaFace, D. M., et al. (1995). Early redistribution of plasma membrane phosphatidylserine is a general feature of apoptosis regardless of the initiating stimulus: inhibition by overexpression of Bcl-2 and Abl. J. Exp. Med. 182 (5), 1545-1556. doi:10.1084/jem.182.5.1545

Mayer, A. M. S., Guerrero, A. J., Rodríguez, A. D., Taglialatela-Scafati, O., Nakamura, F., and Fusetani, N. (2020). Marine pharmacology in 2014-2015: marine compounds with antibacterial, antidiabetic, antifungal, anti-inflammatory, antiprotozoal, antituberculosis, antiviral, and anthelmintic activities; affecting the immune and nervous systems, and other miscellaneous mechanisms of action. Mar. Drugs 18 (1), 5. doi:10.3390/md18010005

McComb, S., Chan, P. K., Guinot, A., Hartmannsdottir, H., Jenni, S., Dobay, M. P., et al. (2019). Efficient apoptosis requires feedback amplification of upstream apoptotic signals by effector caspase-3 or -7. Sci. Adv. 5, eaau9433. doi:10.1126/ sciadv.aau9433

Miao, F. P., Liang, X. R., Liu, X. H., and Ji, N. Y. (2014). Aspewentins A-C, norditerpenes from a cryptic pathway in an algicolous strain ofAspergillus wentii. J. Nat. Prod. 77 (2), 429-432. doi:10.1021/np401047w

Miller, K. I., Qing, C., Sze, D. M. Y., and Neilan, B. A. (2012). Investigation of the biosynthetic potential of endophytes in traditional Chinese anti-cancer herbs. Plos One 7 (5), e35953. doi:10.1371/journal.pone. 0035953

Minarni Artika, I. M., Artika, H., Bermawie, N., Riyanti, E. I., Hasim, A. E. Z., and Hasan, A. E. Z. (2017). Anticancer activity test of ethyl acetate extract of endophytic fungi isolated from soursop leaf (Annona muricata L). Asian Pac. J. Trop. Med. 10 (6), 566-571. doi:10.1016/j.apjtm.2017.06.004

Mohamad, O. A. A., Li, L., Ma, J. B., Hatab, S., Xu, L., Guo, J. W., et al. (2018). Evaluation of the antimicrobial activity of endophytic bacterial populations from Chinese traditional medicinal plant licorice and characterization of the bioactive secondary metabolites produced by Bacillus atrophaeus against Verticillium dahliae. Front. Microbiol. 9, 924. doi:10.3389/fmicb.2018.00924

Motadi, L. R., Choene, M. S., and Mthembu, N. N. (2020). Anticancer properties of Tulbaghia violacea regulate the expression of p53-dependent mechanisms in cancer cell lines. Sci. Rep. 10, 12924. doi:10.1038/s41598-020-69722-4

Namvar, F., Mohamad, R., Baharara, J., Zafar-Balanejad, S., Fargahi, F., and Rahman, H. S. (2013). Antioxidant, antiproliferative, and antiangiogenesis effects of polyphenol-rich Seaweed (Sargassum muticum). Biomed. Res. Int. 2013, 1. doi:10.1155/2013/604787

Navarri, M., Jégou, C., Bondon, A., Pottier, S., Bach, S., Baratte, B., et al. (2017). Bioactive metabolites from the deep subseafloor fungus Oidiodendron griseum UBOCC-A-114129. Mar. Drugs 15 (4), 111. doi:10.3390/md15040111
Navya, P. N., Kaphle, A., Srinivas, S. P., Bhargava, S. K., Rotello, V. M., and Daima, H. K. (2019). Current trends and challenges in cancer management and therapy using designer nanomaterials. Nano Convergence 6, 23. doi:10.1186/s40580019-0193-2

Nurgali, K., Jagoe, R. T., and Abalo, R. (2018). Editorial: adverse effects of cancer chemotherapy: anything new to improve tolerance and reduce sequelae? Front. Pharmacol. 9, 245. doi:10.3389/fphar.2018.00245

Padmavathi, A. R., Abinaya, B., and Pandian, S. K. (2014). Phenol, 2,4-bis(1,1dimethylethyl) of marine bacterial origin inhibits quorum sensing mediated biofilm formation in the uropathogenSerratia marcescens. Biofouling 30 (9), 1111-1122. doi:10.1080/08927014.2014.972386

Pan, F., Liu, Z. Q., Chen, Q., Xu, Y. W., Hou, K., and Wu, W. (2016). Endophytic fungus strain 28 isolated from Houttuynia cordata possesses wide-spectrum antifungal activity. Braz. J. Microbiol. 47 (2), 480-488. doi:10.1016/j.bjm.2016.01.006

Perelman, A., Wachtel, C., Cohen, M., Haupt, S., Shapiro, H., and Tzur, A. (2012). JC-1: alternative excitation wavelengths facilitate mitochondrial membrane potential cytometry. Cell Death Dis. 3, e430. doi:10.1038/cddis.2012.171

$\mathrm{Pu}, \mathrm{X}$., Qu, X., Chen, F., Bao, J., Zhang, G., and Luo, Y. (2013). Camptothecin-producing endophytic fungus Trichoderma atroviride LY357: isolation, identification, and fermentation conditions optimization for camptothecin production. Appl. Microbiol. Biotechnol. 97, 9365-9375. doi:10.1007/s00253-013-5163-8

Pucci, B., Kasten, M., and Giordano, A. (2000). Cell cycle and apoptosis. Neoplasia 2 (4), 291-299. doi:10.1038/sj.neo.7900101

Ravi, L., and Krishnan, K. (2017). Cytotoxic potential of n-hexadecanoic acid extracted from Kigelia pinnata leaves. Asian J. Cell Biol. 12, 20-27. doi:10.3923/ ajcb.2017.20.27

Sajna, K. V., Kamat, S., and Jayabaskaran, C. (2020). Antiproliferative role of secondary metabolites from Aspergillus unguis AG 1.1 (G) isolated from marine macroalgae enteromorpha sp. by inducing intracellular ROS production and mitochondrial membrane potential loss leading to apoptosis. Front. Mar. Sci. 7, 543523. doi:10.3389/fmars.2020.543523

Savage, R. L., Hill, G. R., BarnesKenyon, J. S. H., and Tatley, M. V. (2019). Suspected hepatotoxicity with a supercritical carbon dioxide extract of Artemisia annua in grapeseed oil used in New Zealand. Front. Pharmacol. 10, 1448. doi:10.3389/fphar.2019.01448

Shakeri, A., Cicero, A. F. G., Panahi, Y., Mohajeri, M., and Sahebkar, A. (2018). Curcumin: a naturally occurring autophagy modulator. J. Cell Physiol. 234 (5), 5643-5654. doi:10.1002/jcp.27404

Singh, B., Sharma, P., Kumar, A., Chadha, P., Kaur, R., and Kaur, A. (2016). Antioxidant and in vivo genoprotective effects of phenolic compounds identified from an endophytic Cladosporium velox and their relationship with its host plant Tinospora cordifolia. J. Ethnopharmacol. 194, 450-456. doi:10.1016/j.jep.2016.10.018

Spradlin, J. N., Hu, X., Ward, C. C., Brittain, S. M., Jones, M. D., Ou, L., et al. (2019). Harnessing the anti-cancer natural product nimbolide for targeted protein degradation. Nat. Chem. Biol. 15, 747-755. doi:10.1038/s41589-019-0304-8

Suzuki, Y., Hasegawa, H., Tsuji, T., Tsuruda, K., Sasaki, D., Ishihara, K., et al. (2013). Relationships of diverse apoptotic death process patterns to mitochondrial membrane potential $(\Delta \psi \mathrm{m})$ evaluated by three-parameter flow cytometric analysis. Cytotechnology 65 (1), 59-70. doi:10.1007/s10616-012-9455-0

Toné, S., Sugimoto, K., Tanda, K., Suda, T., Uehira, K., Kanouchi, H., et al. (2007). Three distinct stages of apoptotic nuclear condensation revealed by time-lapse imaging, biochemical and electron microscopy analysis of cell-free apoptosis. Exp. Cell Res. 313 (16), 3635-3644. doi:10.1016/j.yexcr.2007.06.018

Trachootham, D., Alexandre, J., and Huang, P. (2009). Targeting cancer cells by ROS-mediated mechanisms: a radical therapeutic approach? Nat. Rev. Drug Discov. 8 (7), 579-591. doi:10.1038/nrd2803

Uzma, F., Mohan, C. D., Hashem, A., Konappa, N. M., Rangappa, S., Kamath, P. V., et al. (2018). Endophytic fungi-alternative sources of cytotoxic compounds: a Review. Front. Pharmacol. 9, 309. doi:10.3389/fphar.2018.00309

Veeresham, C. (2012). Natural products derived from plants as a source of drugs. J. Adv. Pharm. Tech. Res. 3 (4), 200. doi:10.4103/2231-4040.104709

Wahaibi, A. S. M., Emilia, L., Nithyalakshmy, R., Sergey, D., Robert, U., and Grant, B. G. (2019). Secretion of Dnases by marine bacteria: a culture based and bioinformatics approach. Front. Microbiol. 10, 969. doi:10.3389/fmicb.2019.00969

Wang, C., Zhang, Z., Wang, Y., and He, X. (2015). Cytotoxic indole alkaloids against human leukemia cell lines from the toxic plant peganum harmala. Toxins 7, 4507-4518. doi:10.3390/toxins7114507 
Wang, H., Zhang, T., Sun, W., Wang, Z., Zuo, Z., Li, S., et al. (2016). Erianin induces G2/M-phase arrest, apoptosis, and autophagy via the ROS/JNK signaling pathway in human osteosarcoma cells in vitro and in vivo. Cell Death Dis. 7, 2247. doi:10.1038/cddis.2016.138

Wang, M., Liu, F., Crous, P. W., and Cai, L. (2017). Phylogenetic reassessment of Nigrospora: ubiquitous endophytes, plant and human pathogens. Persoonia 39, 118-142. doi:10.3767/persoonia.2017.39.06

Wu, J., Platero-Luengo, A., Sakurai, M., Sugawara, A., Gil, M. A., Yamauchi, T., et al. (2017). Interspecies chimerism with mammalian pluripotent stem cells. Cell 168 (3), 473-486. doi:10.1016/j.cell.2016.12.036

$\mathrm{Xu}$, J. (2015). Bioactive natural products derived from mangrove-associated microbes. RSC Adv. 5 (2), 841-892. doi:10.1039/C4RA11756E

Yang, Y., Karakhanova, S., Hartwig, W., D’Haese, J. G., Philippov, P. P., Werner, J., et al. (2016). Mitochondria and mitochondrial ROS in cancer: novel targets for anticancer therapy. J. Cell. Physiol. 231 (12), 2570-2581. doi:10.1002/jcp.25349

Yao, J., Jiao, R., Liu, C., Zhang, Y., Yu, W., Lu, Y., et al. (2016). Assessment of the cytotoxic and apoptotic eáects of chaetominine in a human leukemia cell line. Biomol. Ther. 24 (2), 147-155. doi:10.4062/biomolther.2015.093

You, Y., He, Q., Lu, H., Zhou, X., Chen, L., Liu, H., et al. (2020). Silibinin induces G2/M cell cycle arrest by activating DRP1-dependent mitochondrial fission in cervical cancer. Front. Pharmacol. 11, 271. doi:10.3389/fphar.2020.00271

Zahedifard, M., Faraj, L. F., Paydar, M. J., Looi, C. Y., Hajrezaei, M., Hasanpourghadi, M., et al. (2015). Synthesis, characterization and apoptotic activity of quinazolinone Schiff base derivatives toward MCF-7 cells via intrinsic and extrinsic apoptosis pathways. Sci. Rep. 5, 11544. doi:10.1038/srep11544

Zhang, P., Li, X., and Wang, B. G. (2016). Secondary metabolites from the marine algal-derived endophytic fungi: chemical diversity and biological activity. Planta Med. 82, 832-842. doi:10.1055/s-0042-103496

Zheng, Y. M., Shen, J. Z., Wang, Y., Lu, A. X., and Ho, W. S. (2016). Anti-oxidant and anti-cancer activities of Angelica dahurica extract via induction of apoptosis in colon cancer cells. Phytomedicine 23, 1267-1274. doi:10.1016/j.phymed.2015.11.008

Zhu, W., Chiu, L. C. M., Ooi, V. E. C., Chan, P. K. S., and Ang, P. O., Jr. (2006). Antiviral property and mechanisms of a sulphated polysaccharide from the brown alga Sargassum patens against Herpes simplex virus type 1 . Phytomedicine 13, 695-701. doi:10.1016/j.phymed.2015.11.008

Conflict of Interest: The authors declare that the research was conducted in the absence of any commercial or financial relationships that could be construed as a potential conflict of interest.

Copyright (c) 2021 Taritla, Kumari, Kamat, Bhat and Jayabaskaran. This is an openaccess article distributed under the terms of the Creative Commons Attribution License (CC BY). The use, distribution or reproduction in other forums is permitted, provided the original author(s) and the copyright owner(s) are credited and that the original publication in this journal is cited, in accordance with accepted academic practice. No use, distribution or reproduction is permitted which does not comply with these terms. 